\title{
How can Landscape Design Improve the Social and Psychological Conditions in the City Improving the Ecological Stew- ardship of Water?
}

\section{By}

\section{Maria Carrier}

A thesis submitted to the Faculty of Graduate and Post Doctoral Affairs in partial fulfillment of the requirements for the degree of

Master of Architecture

\author{
Carleton University \\ Ottawa, Ontario
}

(C) 2012

Maria Carrier 
Library and Archives

Canada

Published Heritage

Branch

395 Wellington Street

Ottawa ON K1A ON4

Canada
Bibliothèque et

Archives Canada

Direction du

Patrimoine de l'édition

395 , rue Wellington

Ottawa ON K1A ON4

Canada
Your file Votre référence

ISBN: 978-0-494-91516-5

Our file Notre référence

ISBN: 978-0-494-91516-5
NOTICE:

The author has granted a nonexclusive license allowing Library and Archives Canada to reproduce, publish, archive, preserve, conserve, communicate to the public by telecommunication or on the Internet, loan, distrbute and sell theses worldwide, for commercial or noncommercial purposes, in microform, paper, electronic and/or any other formats.

The author retains copyright ownership and moral rights in this thesis. Neither the thesis nor substantial extracts from it may be printed or otherwise reproduced without the author's permission.
AVIS:

L'auteur a accordé une licence non exclusive permettant à la Bibliothèque et Archives Canada de reproduire, publier, archiver, sauvegarder, conserver, transmettre au public par télécommunication ou par l'Internet, prêter, distribuer et vendre des thèses partout dans le monde, à des fins commerciales ou autres, sur support microforme, papier, électronique et/ou autres formats.

L'auteur conserve la propriété du droit d'auteur et des droits moraux qui protege cette thèse. $\mathrm{Ni}$ la thèse ni des extraits substantiels de celle-ci ne doivent être imprimés ou autrement reproduits sans son autorisation.
In compliance with the Canadian Privacy Act some supporting forms may have been removed from this thesis.

While these forms may be included in the document page count, their removal does not represent any loss of content from the thesis.
Conformément à la loi canadienne sur la protection de la vie privée, quelques formulaires secondaires ont été enlevés de cette thèse.

Bien que ces formulaires aient inclus dans la pagination, il n'y aura aucun contenu manquant. 


\section{How can Landscape De- sign Improve the Social and Psychological Conditions in the City Improving the Ecological Stewardship of Water?}

By

Maria Carrier 


\section{Table of Contents}

\section{Abstract:}

Introduction:

\section{The Water Problem}

1.1 Consumption and Pollution: The Global Issue

1.2 Ottawa Water Pollution

2. Water

2.1 Water and Experience

2.2 Clean and Be Cleaned

\section{History}

3.1 The Creation of a City and its Relationship with Water

3.2 City Planning

\section{Case Studies}

4.1 Central Park, New York City, U.S.A.

4.2 The Living Water Garden, Chengdu, China

4.3 The Omega Institute for Holistic Studies, Rhinebeck, U.S.A.

5. Public Park

5.1 Proposal

5.2 Design Aspirations

6. Site

6.1 The Experimental Farm, Ottawa

7. Public Park and Water Treatment 
7.1 The Proposed Water Treatment

7.2 Program for a Water Treatment Facility in Ottawa

8. Water System Calculations

8.1 Vocabulary

8.2 Primary Treatment Using Duckweed

8.3 Hyacinth Detention Time

8.4 Design Parameters: Secondary Water Hyacinth - Non Aerobic

8.5 Domestic Water Consumption for Ottawa, Canada

8.6 The Experimental Farm, Maps and Images

8.7 Site Choices

9. Water Treatment and Park Design

9.1 Design

10. Conclusions

Illustrations

Bibliography 


\section{Abstract:}

This thesis explores, through architectural design, the potential for human habitation to occur alongside a positive impact on the environment. Using water as the focal point, it will explore through architectural and landscape design how water resources for the city can be localized. Clean water can benefit the city both ecologically and socially. This design aspires to provide a sensual experience of water to benefit the public spaces of the city of Ottawa, while educating the public about responsible interaction with this fragile resource.

Water is about balance. It has a dual symbolism as it is both an agent that cleans and an agent that purifies. Too much or too little water equals death for most creatures. The nature of water is sensitive and sacrificial. To clean, it must take the dirt as its own burden. The burden is now on us to preserve this precious resource; "... [we must] reflect on the bond the imagination creates between two kinds of stuff from which a city is made: urban space and urban water." This research is about water as a landscape material, water as a resource, and how both of these aspects affect the urban condition. 


\section{Introduction:}

Atticiam: Referring to Greek refinement; a word or form characteristic of Attic Greek; style of language from that time period. Oxford Dictionary
There is much current discussion concerning the environmental impact human beings have on this planet. The word ecology, originally derived from the word "economy", is similarly related to management. It developed out of a concern for habitat during the eighteenth century. ${ }^{1}$ It can also be linked to the Latin verb "it lives". The word was used to describe the relations between animals, their interactions with each other, and their habitats. ${ }^{2}$ After the 1950 s the western society became more interested in action against pollution, and ecology took on a new meaning to incorporate "concern with conservation". ${ }^{3}$ In the late sixteenth century, naturalism was used as a negative expression to describe human behavior that went against God's will. It was used to explain why people acted against God. Naturalism was associated with atticism, which also was seen as a negative way of thinking, because the study of science had not yet become socially accepted to the rest of Europe. The word was used for people seen as natural philosophers, who we now call scientists. Starting in the middle of the nineteenth century naturalism described a group of painters who closely observed details on natural objects or landscapes and attempted to recreate them as realistically as possible. Today the term primarily means "an accurate external representa-

\footnotetext{
1 Williams, Keywords, 110.

2 Williams, Keywords, 111.

3 Willams, Keywords, 111.
} 
Land being: developments, farming, cities etc.

Environment such as: Pollution from cars landfill and other sources have effected the global climate, referred to as global warming tion" for art. ${ }^{4}$

It can be said: ecology is the management of living things within their habitat. As humans have manipulated most of the land and environment globally, it can be argued that our environment is natural only in its early definition, which actually means unnatural or super-natural. Hence, the previous statement can be modified to: ecology is the management of living things within their (super)natural habitat.

There is currently a need in North American society for sustainable design in architecture. In many cases sustainability is a word that is used to describe how a building or consumer item has a low carbon output and, thus, less environmental impact. In spite of our efforts to reduce carbon output, recent reports indicate our current rate of resource consumption still does not support our planet's ecosystems. ${ }^{5}$ For example, consumers are still buying bottled water when Canadians have one of the largest supply of fresh water in the world. Why do we rely on water that needs to be transported and bottled? According to National Geographic Magazine, in 2006 the equivalent of two billion half-litter bottles of water arrived in U.S. ports, based on reports from Natural Resources Defense Council (NRDC). ${ }^{6}$

"[The island of ] Fiji shipped 18 million gallons of bottled water to California, releasing about 2,500 tons of transportation-re-

4 Williams, Keywords, 218.

5 Reports from: Rees. Understanding Urban Ecosystems, 121. And "National Geographic", greenliving.nationalgeographic.com.

6 Didler, "Water Bottle Pollution Facts", greenliving.nationalgeographic.com. 
lated pollution. Western Europe's shipment of bottled water to New York City that year released 3,800 tons of pollution."7

Although water bottles can be recycled, over 80 percent are dumped into that nation's landfill (U.S.). It takes 17 million barrels of crude oil to manufacture the 29 billion water bottles purchased by Americans each year. ${ }^{8}$ There is a negative side effect to almost every aspect of water bottle production. Considering that water can be obtained locally within the city either by lake, river, pond or well for a much cheaper price, disposable water bottles do not make environmental sense. But this of course assumes we have protected our water sources.

Pollution has negative long-term effects on the environment. Landfill sites are known to release chemicals into the soil, contaminating the local landscape, including ground water, lakes and rivers. One article reported: "...Groundwater contamination may commence years after the waste source is in place. The slow release rate causes it to take years to thousands of years to move through the groundwater flow regime, and groundwater can be difficult, if not impossible to remediate,[and is always] prohibitively costly to remediate. Ultimately, all contaminated groundwater will discharge to surface water. Thus, should serious groundwater contamination occur, the destruction of drinking water supplies and aquatic ecosystems occurs for decades to hundreds of years."

The two main landfill sites in Ottawa are the Trail Road Waste Facility, located to the southwest of the city close to New Barrhaven, and the second is Springhill Landfill, which is close to Navan. ${ }^{10}$ Both of the city's landfill sites are in locations that are rural and almost at the edge of the city's legal boundaries. The majority of

\footnotetext{
7 Didler, "Water Bottle Pollution Facts", greenliving.nationalgeographic.com.

8 Didler, "Water Bottle Pollution Facts", greenliving.nationalgeographic.com.

9 Crowe, Ptacek, Rudolph and McGregor. "Threats to Sources of drinking Water and Aquatic Ecosystem Health in Canada", umw.ec.gc.ca.
}

10 City of Ottawa Landfill Sites, www.ottawa.ca 
a city's resources are produced from the surrounding rural land. That said, ground water contamination of lands surrounding a city affects the overall ability to provide food, water and other resources. The seven deaths in Walkerton, Ontario, are a direct result of the improper disposal of animal waste that contaminated the local water supply in May 2000.11

Canadian fresh water lakes and rivers still continue to be polluted with little regard for the environmental repercussions. Cities need to start cleaning water resources and localize the water consumed. As the typical North American city does not renew its own recourses, it has yet to become a functional ecosystem. Functional in the sense that it is more than simply a consumer of goods. Nature works in a cyclical pattern wasting nothing. Renewal of raw materials is critical to the successful continuation of our cities. The following research explores specific ways in which the city can play a positive and integrated role in the management of its water.

11 Crowe, Ptacek, Rudolph and McGregor, "Threats to Sources of drinking Water and Aquatic Ecosystem Health in Canada", unw.ec.gc.ca. 
"Marco Polo reported: "Hell-if there be such a thingis not tomorrow, hell is right here, and there are two ways to avoid suffering in this Hell. The first way out is easy for most people: Let hell be, live it up, and stop noticing it. The second way is risky. It demands constant attentive curiosity to find out who and what in the midst of this hell is not part of it, so as to make it last by giving space to it." Only those who recognize the nightmare of nondiscrete space can regain the certainty of their own intimacy and thereby dwell in the presence of one another."

lilich. $\mathrm{H} 2 \mathrm{O}$ and the Waters of Forgetfulness. 22 


\section{The Water Problem}

\subsection{Consumption and Pollution: The Global Issue}

Each year millions of litres of polluted water flows from our cities and towns. This water collects in places such as the Gulf of Mexico, creating an 8,000 square mile "dead zone". ${ }^{12}$ Dead zones cannot support aquatic life and therefore the greater ecosystem suffers. People cannot eat food or drink water that comes from such a water source; it can cause birth defects, illness, and death. Many places such as Europe are implementing new policies and laws to deal with the stress on the environment caused by water pollution. Water contamination can happen in many ways such as via human waste, industrial waste, air pollution causing acid rain, ground water contamination, and agriculture, to name a few. The European Water Framework Directive (WFD) is mandated to protect and manage water across the European Union (EU). They have a goal to clean most bodies of water in the EU to the equivalent of "good ecological status" by $2015 .{ }^{13}$

Canada has one of the largest supplies of fresh water rivers and lakes in the world. Canada also has one of the largest coastlines. This puts the country in a position of both power and responsibility: it gives us power because we have an abundant supply of a valuable resource. The responsibility lies in protecting that resource from becoming polluted. Water is arguably one of the most precious natural resources on the planet. This resource is so precious and scarce that it could be fought over in the decades to come.

So what has Canada done to protect this valuable resource? Though our population density as a country is low, Canadians have still had a negative impact

12 Wals-Thumma, How can water Polkution Affect Animals, Homes and Heath? greenliving.nationalgeographic.com

13 Church, The attitudes of recreational user representatives to pollution reduction and the implementation of the European Water Framework Directive, 167. 


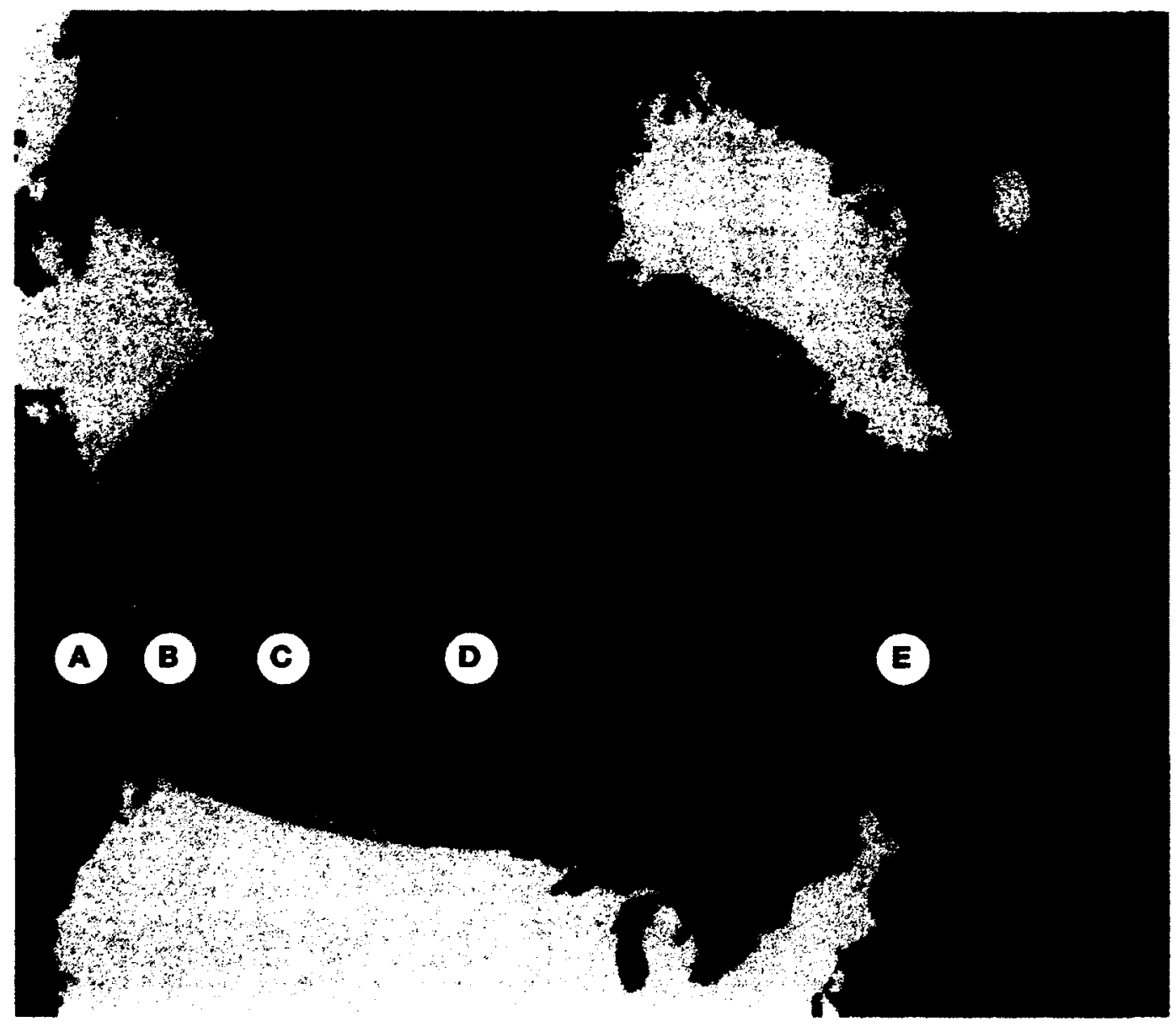

Figure1: Average Canadian Water Consumption Per Person Per Day

A) $0.39 \mathrm{~m}^{3}$; B) $0.92 \mathrm{~m}^{3}$; C) $<0.160 \mathrm{~m}^{3}$; D) $0.24 \mathrm{~m}^{3} ; \theta 0.39 \mathrm{~m}^{3}$.

on our water. The map below shows our domestic water needs per person per day. Canada comes second next to the United Stated in domestic water consumption among industrialized countries. Pollution in Canadian waters is primarily from untreated sewage.

\subsection{Ottawa Water Pollution}

The Experimental Farm in Ottawa, Ontario will be the site for which this project is proposed. It is commonly known that Ottawa has an antiquated sewage system. When the system has more waste than it can handle, water bypasses 
the wastewater treatment center and directly enters the Ottawa River. The city of Ottawa's annual sewer overflow report indicated that $424,000 \mathrm{~m}^{3}$ of sewage bypassed the water treatment plant and entered directly into the Ottawa River last year. ${ }^{14}$

The city of Ottawa has polluted the rivers to such a degree that it results in frequent closures of many beaches, such as Mooney's Bay, due to harmful levels of bacteria. This past year the CBC news reported 124 "no swim" advisories throughout the summer. Beach closures have increased two and a half times from the previous summers ( 47 advisories). ${ }^{15}$ The loss of a beach is the loss of a public space. When people live in high-density urban conditions, public parks and recreation spaces are critical to relieve social and economical stresses. ${ }^{16}$

As mentioned, the WFD (European Water Framework Directive) was created to protect bodies of water across the EU. One of their main objectives is to clean water for the benefit of recreation. Among the commercial and ecological advantages of clean public water, the WFD studies have shown that public opinion of water affects levels of water recreation activities. "...some studies note that the determining factor in participation is often people's perceptions of water quality, rather than the actual levels of pollution, or any scientific evidence about the impact of the pollution on human health and well-being." ${ }^{17}$ That said, even though Ottawa water has "no swim" advisories, days that are "safe" to swim will not attract a large number of people. Suggested reasons for the advisories are bird droppings from sanctuaries close to the beaches. However, that would suggest there was an

142010 Annual Combined Sewer Overflow Control Period Reporting, June 3, 2011.

15 Giacomo, Panico. "Wildife Fouling Ottawa beaches", CBC Nows, Aug 21, 2011.

16 Cities of the nineteenth century suffered from overcrowding, poor sunlight and nonexistent ventilation. Those who could afford too, had homes outside the city to escape the pollution.

17 Church. The attitudes of recreational user representatives to pollution reduction and the implementation of the Europeen Water Framework Directive, 168. 
increase in bird populations around the said areas.

Citizens become weary of their beaches, and will have a general negative perception of that body of water. Their opinion influences their interaction with the given body of water more than the physical condition of it. This same perception is what drives some people to use bottled water. There is a common misconception that bottled water is cleaner than tap water, influencing many to drink bottled water when they otherwise would not. 


\section{Water}

\subsection{Water and Experience}

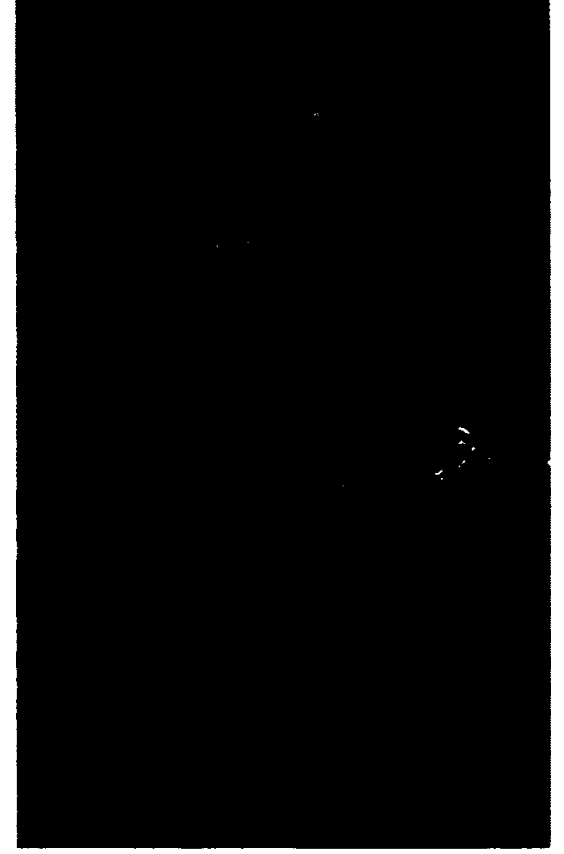

Figuree: Pond

"...creation starts in the womb, in which the waters fuse."

litich, $\mathrm{H}_{2} \mathrm{O}$ and the Waters of Forgetfulness, 25

Life started in water, and even now though many creatures have come to live on land. water can only be transported with us, we will never be entirely independent of it.

"The "stuff" of life, water...There are between twelve and fourteen chemicals applied to drinking water before you get it. What you get is a sterile product with certainly dubious drinking water quality. And it really represents a failure of how we think about water."18

Modern society has turned water into "stuff" that must be regulated and legalized. For example, developed cities must continually address water irrigation for rain run off, sewage treatment, potable water, and legalities about how water may be used commercially and residentially. Our perception of water as a life giving force has ironically been changed by modern day science into a nuisance called " $\mathrm{H}_{2} \mathrm{O}$ ", which ruins buildings, cracks the roads, and rusts cars.

The relationship between science and ways of seeing were very well described by the philosopher Maurice Merleau-Ponty who wrote on the subject of phenomenology, "...Synaesthetic perception is the rule, and we are unaware of it only because scientific knowledge shifts the center of gravity of experience, so that we have unlearned how to see, hear, and generally speaking, feel, in order to deduce, from our bodily

\footnotetext{
18 Berkebile, McDowell, Stephen and Lesniewski, Flow, 5.
} 
organization and the world as the physicist conceives it, what we are to see, hear, and feel." 19

Ways of perception as described by Merleau-Ponty are purely individual experiences. Science has attempted to quantify our sensory experiences and categorize them into specific definitions. For example, sounds can be measured in decibels to record loudness. This is done using the power of the electronic current powering the sound system. The result is numeric, indicated by a machine telling us how loud we hear it. Receiving information this way completely removes one from the experience of actually hearing, for ourselves, how loud something is. This shifts the way we experience through our sensory knowledge. Thus, we have removed ourselves from the experience itself. When it comes to water we analyze it with this same level of objectivity; this project aims to re-establish forgotten subjective sensual experiences.

The way society looks at water today has this same "shifted center of gravity". ${ }^{20}$ Water of the twenty-first century is used as a tool to accomplish some other goal. Even in the case of the swimming pool in local backyards, many ultimately harmful chemicals are added to make water seemingly "safe" and "sanitary". It is ironic that water should be the agent to clean and yet we must add chemicals to keep it clean. Chlorine is not good for people or the environment as it is an eye and ear irritant. Chlorine can cause damage when inhaled, and also kills fish and other aquatic life. It is most commonly used for its inexpensive and low maintenance capabilities. Despite other methods for cleaning water, such as salt water or ozone systems, people are not willing to pay the higher cost for a better product. ${ }^{21}$ These types of decisions demonstrate how water in the twenty-first century

19 Ibid., 228. From: Abram, The Spell of the Sensuous, 60.

20 Ibid., 228. From: Abram, The Spell of the Sensuous, 60 
is simple "stuff" to be used however and when ever we wish. We fail to recognize the beauty and power of the water itself. We use it for what it can do, but do not respect it for what it is.

\subsection{Clean and Be Cleaned}

Water has a dual symbolism as it is both an agent to itself clean dirt off

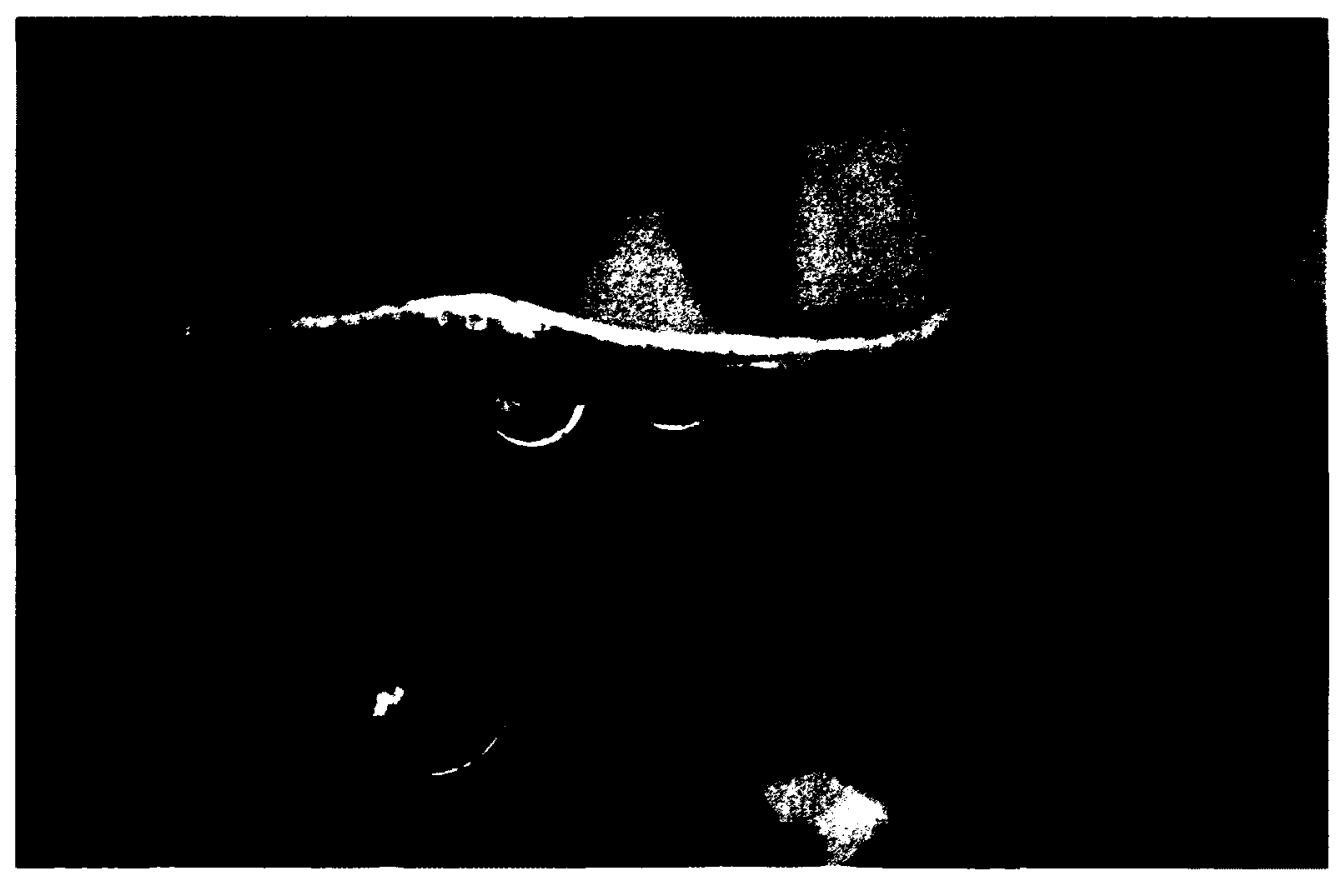

Figures: Water Drops on Orchid

the surface or "skin" of something and an agent to purify. "Water communicates its purity by touching or waking the substance of a thing and it cleans by washing dirt from its surface." ${ }^{22}$ Although, to perform purification rituals, water is not always needed; other such purification methods involve: blood, fire, chanting etc.. As previously discussed, water has taken on a material meaning almost stripped of its previous value in society. Water is ironic because it is a symbol of purity and is used to clean, to do so water takes the burden of impurity onto itself. We must dirty clean water so that we may feel clean and in the process the water has now 
Jeremy Bentham was an author, jurist, philosopher and social reformist among other things.

Circulate; During the eighteenth century the term circulate was being related to blood and no other liquids, it was not until later that circulation was used to describe the movement of water. become dirty. Once polluted water no longer has the same appeal for us.

When it comes to a body of water, we are still drawn to it. Homes with a waterfront view will be more expensive that those without. "We feel free to criticize the way he [the architect] displays it [water], makes it dance or sparkle. But we do not feel free to question the natural beauty of water itself because we know, yet cannot bear to acknowledge, that this "stuff" is recycled toilet flush." ${ }^{23}$ We take water's beauty for granted and judging by our actions of pollution, we do not respect it.

Water is about balance. When water moves, the rhythm is a back and forth movement. Too much or too little equals death for most creatures. Water must circulate constantly to complete its natural flow. ${ }^{24}$ "In 1842 Sir Edwin Chadwick, former literary assistant to Jeremy Bentham and afterwards member of the Royal Commission on the Poor Laws, presented a report on the sanitary conditions of the laboring populations... In this report Chadwick imagined the new city as a social body though which water must incessantly circulate, leaving [the city] again as dirty sewage. Without interruption water ought to "circulate" through the city to wash it of its sweat and excrement wastes."25 


\section{History}

\subsection{The Creation of a City and its Relationship with Water}

Historically, cities were created around a water source. Settlements were completely reliant on having a local water supply. These fresh bodies of water provided food and drinking water. Salt water provided food via fish and seafood; however, the population had to obtain drinking water another way. "Early settlements had depended on rivers, ponds, and enclosed springs from which water was occasionally channeled to a nearby temple or palace. ${ }^{28}$ In the case of Venice, Italy, the city used a roof system which gathered the rain water into a well. ${ }^{27}$ This water would pass through sands placed in the court yards of homes which would help clean the water before entering the well. Evidence of rainwater collection has been found throughout history as far back as $4000 \mathrm{BC} .{ }^{28}$ "The art of well digging was perfected after 2500 B.C.. Egyptians learned to "mine" water, to increase the output of their wells by driving horizontal tunnels into the strata at the bottom of the hole they had dug." ${ }^{29}$ It was at this point that ancient civilizations started building cities farther and farther away from their open and obvious fresh water sources.

In Virtuvius's Ten Books Di Architettura he wrote to Caesar Augustus about appropriate sites for a city. He emphasized the need to determine whether or not a site was healthy, free of disease and famine. He also indicated that "...the choice of the most healthy site. Now this will be high and free from clouds and hoar frost, with an aspect neither hot nor cold but temperate. Besides, in this way a marshy neighbourhood shall be avoided." 30 Vitruvius believed that the marsh waters were

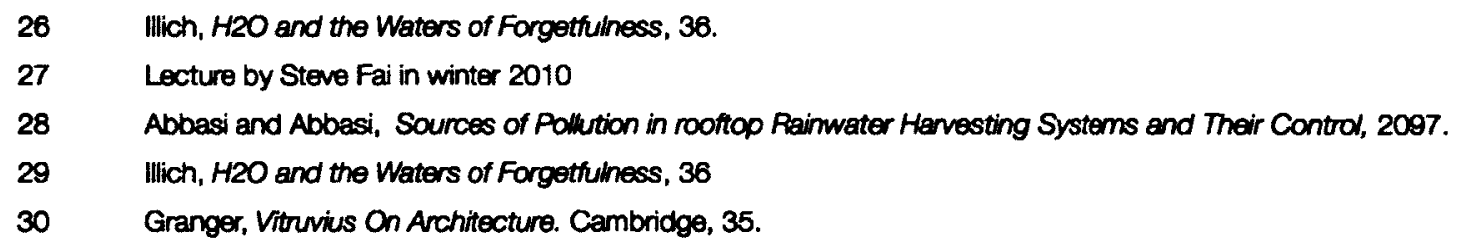


polluted and moist air carried by the wind would harm those who came into contact with it. He suggested in his writings to inspect the livers of the beasts that dwell in the area for the prospective city, claiming that the healthy animals would indicate a healthy site. ${ }^{31}$

The Romans began to channel their water in from non-local water sources via aqueducts. These structures became a recognisable landscape feature which allowed the citizens of a city to have access to large amounts of clean, fresh water. One of the design strengths of the aqueduct was that it allowed water to flow, preventing stagnant water, thus, accumulating harmful bacteria. The weakness of such a design was that city dwellers did not have direct contact with their water source. From the perspective of the consumer, water now came from a seemingly endless and easily accessible water supply. The inevitable result, and a problem still today, was a rise in the per capita water consumption rate. A person who must carry water a mile from the well to their home will use water in a much more precious way than those who simply need to turn on a faucet.

\subsection{City Planning}

In the nineteenth century cities had become overpopulated hives of pollution and illness. In many places, such as London, Paris, and New York, those with the power to vote were those who owned property. This translates to the white wealthy male, who had political say. Thus, cities were designed with a very small percentage of the population in mind. Many solutions where proposed as solutions to the Victorian City from writer Ebenezer Howard, and later such architects as Le Corbusier and Frank Lloyd Wright. ${ }^{32}$ As the western city began to transform into the modern version we know today, development and industries started to

31 Granger, Vitruvius On Architecture. Cambridge, 41

32 Hall, Citios of Tomorrow Third Edition, 8-9 
produce in mass amounts. Writer William Rees describes the economics of cities: "...our scientific-industrial culture sees urbanization in the twentieth century mainly as a demographic transition driven by economics abetted by modern technology. We virtually ignore its ecological implications even though the mass "migration" of humans from all over the countryside into cities may well be the most ecologically significant phenomena..."33

The cities of today must plan for the future growth, and that growth needs to consider how resources will be obtained. "Ecological economics was conceived, in part, to reconcile humankind with the rest of the natural world. It treats human beings not as outside nature, but rather as integral components of, and active participants in, the ecosystems that support them. ${ }^{34}$ Our current cities are built on what is called a "dissipative structure", where the output is greater than the available input. ${ }^{35}$ In short, the world will run out of resources with our current consumption rate leading to an economic and social collapse. With that knowledge planners can begin to implement ways to either reduce consumption, and/or increase our available resources. This thesis specifically looks at water management for the city of Ottawa. Cleaning Ottawa's polluted water to help reverse what damage we have done and examining how clean water benefits the city, present and future.

33 Rees, In Understanding Uiban Ecosystems, 120.

34 Rees, In Understanding Urban Ecosystems, 120.

35 Rees, In Understanding Urben Ecosystems, 121. 


\section{Case Studies}

\subsection{Central Park, New York City, U.S.A.}

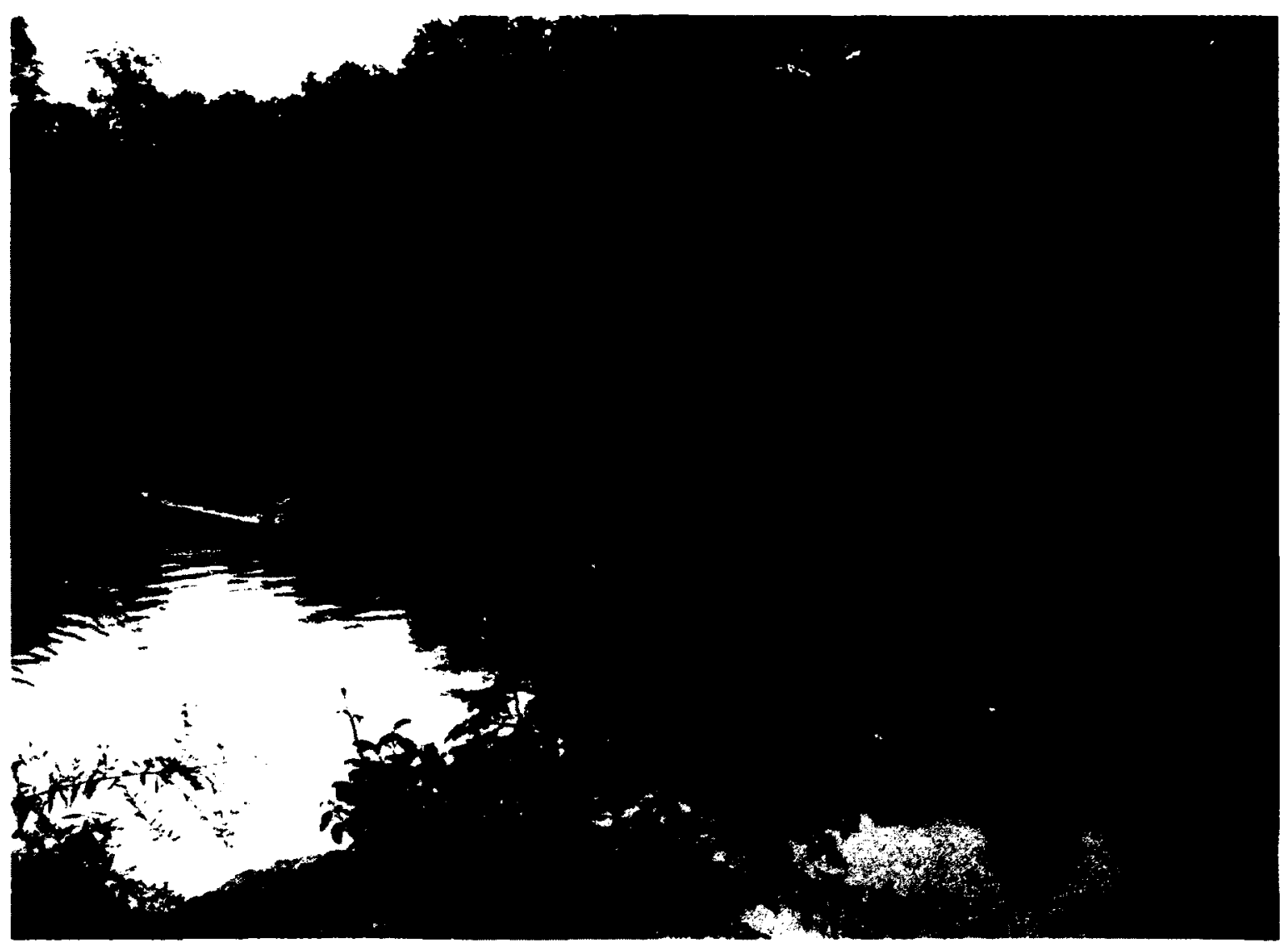

Figurou: Central Park, small pond

In 1858 Frederick Law Olmsted and Calvert Vaux won the competition for the design of Central Park in New York City. The design they proposed was entitled "Greensward". The park covers 843 acres of land in the downtown metropolis of New York City. ${ }^{36}$ This site was not ideal for residential construction due to its marshy land and irregular topography. Before the park was sited there the location was home to Seneca Village, a town for African American and Irish immigrants, as well as "unsightly' and "foul-smelling" industrial buildings. The area was also the 
s.

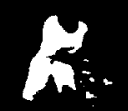

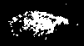

Figures: Mother and Child.

site for the city's water reservoir. The proposal for a public park was a response to several negative conditions created by dense urban living still further south of the site. Such conditions included poor public health, overcrowding in the homes and workplaces, and social alienation..$^{37}$ Olmsted argued that the creation of a park would be the best solution to alleviate many of those problems. By creating public playgrounds that were closely supervised, the children, in particular from immigrant families, could be "molded into orderly and adaptable American

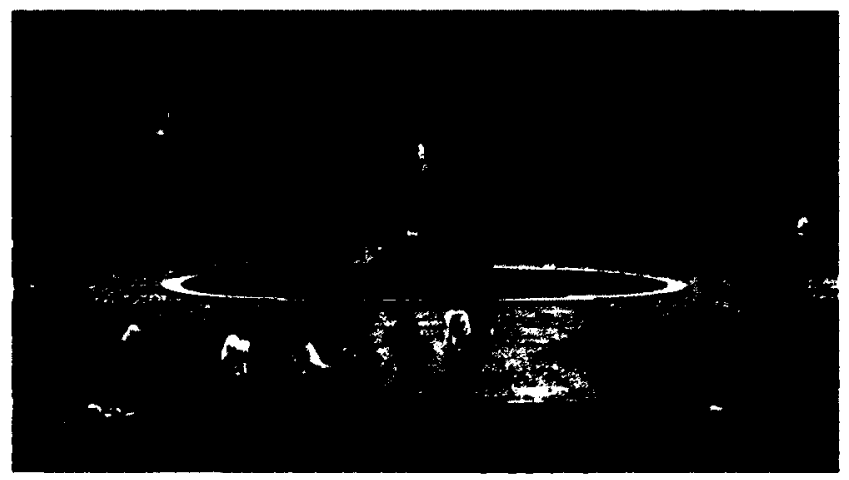

Figures: Children's Outing

37 To be isolated from other social groups and social gatherings. 
Citizens". ${ }^{38}$ The expectation was that these children would then contribute to "new forms of community solidarity"and "remedy social inequalities". ${ }^{39}$

A key contributor to many of the ideas that went into the design of Central Park was Andrew Jackson Downing. He was the earliest significant and prolific writer on the subject of landscape taste, design and how these could effect social reform. Landscape gardening had not been established as an art form at the time of Downing's first published book called $A$ Treatise on the Theory and Practice of Landscape Gardening (1849). It was among the earliest publications to discuss the ornamental values of plants, and was highly popular. He describes naturalist landscapes as "graceful or beautiful". ${ }^{40} \mathrm{He}$ wrote about the utility and beauty of architecture and how the fulfillment of beauty in architecture "... appeals to a wholly different part of our nature; It requires another portion of our being to receive and enjoy it." ${ }^{41}$ Downing believed that gardens affected social behavior and the psychological

\footnotetext{
38 Rosenzweig and Blackmar, The Park and the People, 423.

39 Rosenzweig and Blackmar, The Park and the People, 423.

40 Schuyler, Apostle of Taste, 41.

41 Downing, The Architecture of Country Houses, 8.
}

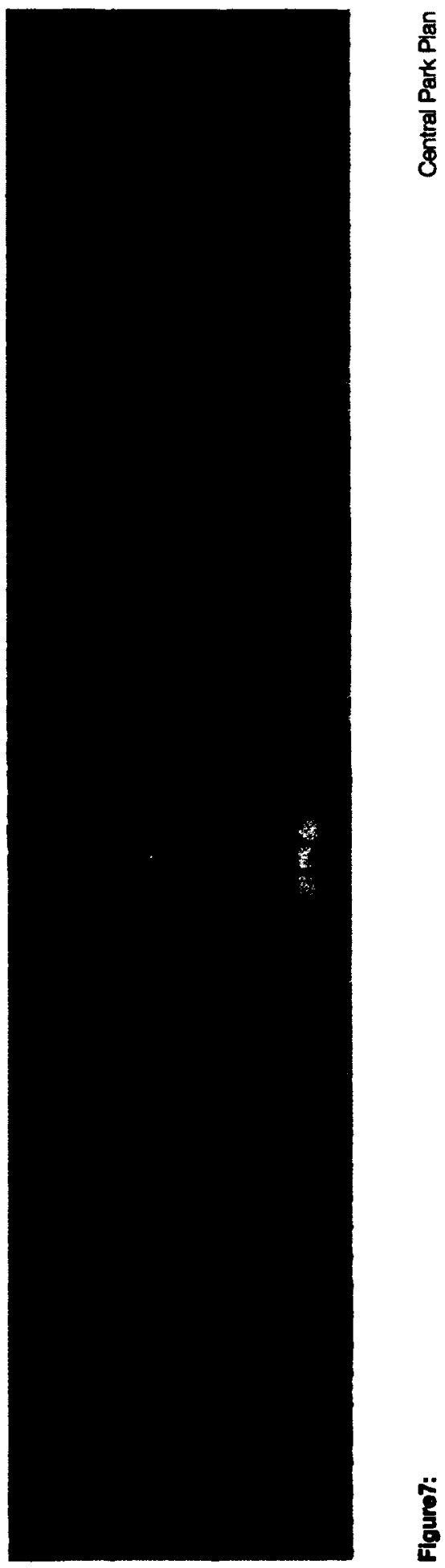


condition of ones mind. "We have said that the Useful in Architecture is based wholly on the physical wants of man; that it is a response to the demand of our senses. We may also add that the Beautiful is an original instinct of the sentiment of our nature. It is a worship by the heart, of a higher perfection manifested in material forms. ${ }^{42}$

Downing identified two kinds of beauty: the Absolute and the Relative. "Absolute beauty lies in the expression, in the material forms, of those ideas of perfection which are universal in their application. We find them in nature as well as in art." Downing indicates that nature is an instinctual origin of beauty for people, because it possesses that higher order of perfection we desire. Gardens satisfy a part of our being that cannot be matched by the simple utility of a building. Thus, in part due to Downing's writing, gardens and landscape design began to be used heavily in the renewal of urban fabrics to satisfy the other needs of the human condition. These ideas are what influenced Vaux, who was a pupil of Downing's, in the creation of a public park to aid in the problematic social issues of New York City. Parks provide that which is missing in the daily life of an urban dweller and, thus, fulfilling desires not satisfied by utility. Downing's ideas influenced the development of many parks across the United States and encouraged the creation of an American landscape style.

While ultimately Central Park's creation can be attributed to the wealthy class, Olmsted and Vaux had other plans for the park; they where able to convince the local government to build a park for the benefit of all social and economic classes. The design of the park has a strong correspondence to that of English garden design. Like the English garden, Central Park has paths that twist, turn and intersect, giving the visitor the feeling that he/she has traveled much farther than 
in actuality. The park's vegetation is placed to look "natural". Plant arrangements were made to look as though they preceded human settlement. "For the designers, the key to the park's enjoyment lay in the healing release that would come from such visual experiences". ${ }^{43}$

The first task in the construction of Central Park was the drainage of the site. Olmsted had four fundamental concerns in the design of site drainage. "To what extent shall the park be drained? (Answer: Totally.) By what form of drains? (Earthenware, of varying calibers.) At what Depth? (Three feet in open glades, four feet in forested areas.) For best economy, by contract or days' work? (By days work...)" ${ }^{44}$ The next task was to set up the circulation through the park. The roadways were largely influenced by the existing topography. The designers completed an extensive analysis of the site's topography to determine where and how the water should be drained, and this in turn played a direct role in the placement of roadways in the park. Roadways need dry land for their foundations, so the roads were built on higher land. Water was pooled in the lower land, opposite of where one would build the roads, therefore, the water and roadways act as opposites to one another.

The relationship between circulation and water provided the designers with opportunities for views and vantage points. According to the designers, the greenery and plants were a means to direct visitors to the greatest number of viewpoints as possible. 45 "...Landscapes where a mixture of mature hardwoods and evergreens [cover] the earth, but always with provision for open space, be it water or grassland." 46 The views of water were of such importance to the design

\footnotetext{
43 Rosenzweig and Blackmar, The Park and the People, 133.

44 Heckscher, Creating Central Park, 40.

45 Heckscher, Creating Central Park, 28.

46 Heckscher, Creeting Central Park, 28.
} 
that instead of the regular driveway Downing would have envisioned, Olmsted and Vaux proposed a bridle path (a large transport route for carriages) around the new reservoir. ${ }^{47}$ "...the natural beauty of a body of water would be morally uplifting to the civic life." 48 This indicates that by the mere presence of water we are affected physiologically in a positive way.

One of the monuments in the park dedicated to healing is a water feature called Bethesda Fountain. The fountain, also known as "The Angel of the Waters", is one of the few sculptures to have been commissioned for the original design by Olmsted.

The new curvilinear reservoir was built north of the pre-existing rectangular reservoir, designed in 1862 . The new reservoir has a more naturalistic esthetic that fit in with the rest of the park's design. What was once uninhabitable marsh land now became scenic lakes. ${ }^{49}$ The lakes became public spaces themselves in the winter, which visitors could skate upon. Thus, the functional reservoirs that provided water for the city also became a picturesque landscape feature and a public recreation space.

Olmsted's interest in solving social problems is one of the strongest themes of the park's design. The park stands in contrast to the rest of the urban landscape; It acts as a courtyard for the city on an urban scale. The downside to the park is that as the city becomes larger and denser the park is unable to grow larger to accommodate more people. People living in new developments will have to travel longer to visit Central Park making it difficult for the park to remain equally accessible.

This project is a good example of a public park that has impacted its city

\footnotetext{
47 Heckscher, Creating Central Park, 36.

48 Illich, $\mathrm{H} 2 \mathrm{O}$ and the Waters of Forgetfuness, 1.

49 uww.centralpark.com
} 
by providing green space attempting to solve social differences among citizens. It takes into consideration the psychological impact a place like this can have on people and recognizes water as a part of this effect. This project stores and transports water through reservoirs and aqueducts but does not clean its water. The park has no ecological goals other than to simply exist in a city filled with traffic and buildings. In other worlds the park is a way to get plants and wildlife into the metropolitan; it does not clean water, use solar lighting or use recycled steal etc., in an effort to be more ecologically conscious.

For my project the water treatment is expected to help reverse some of the pollution inflicted by human habitation. It is also expected that the newly cleaned water will have a city-wide effect on public spaces connected with this body of water. The project will also aim to educate youth, in hopes that, like central park, it will improve the future of the city.

\subsection{The Living Water Garden, Chengdu, China}

Artist Betsy Damon and landscape designer Margie Ruddick designed the Living Water Garden project in 1994-1999. This project is designed to clean a portion of the polluted river water at the intersection of rivers Fu and Nan in downtown Chengdu, China. This project functions both as a water treatment facility and a public park. ${ }^{50}$ The park was created as a part of the municipality's five-year action plan to clean up the rivers of the city and to provide public space for visitors to enjoy. ${ }^{51}$

The park in the Living Water Garden occupies 5.9 acres and cleans an estimated 200 cubic meters of polluted water a day. Once cleaned, the water is

50 Hiew, Live Water Garden, unw.morechengdu.com

51 greenmuseum.org. 


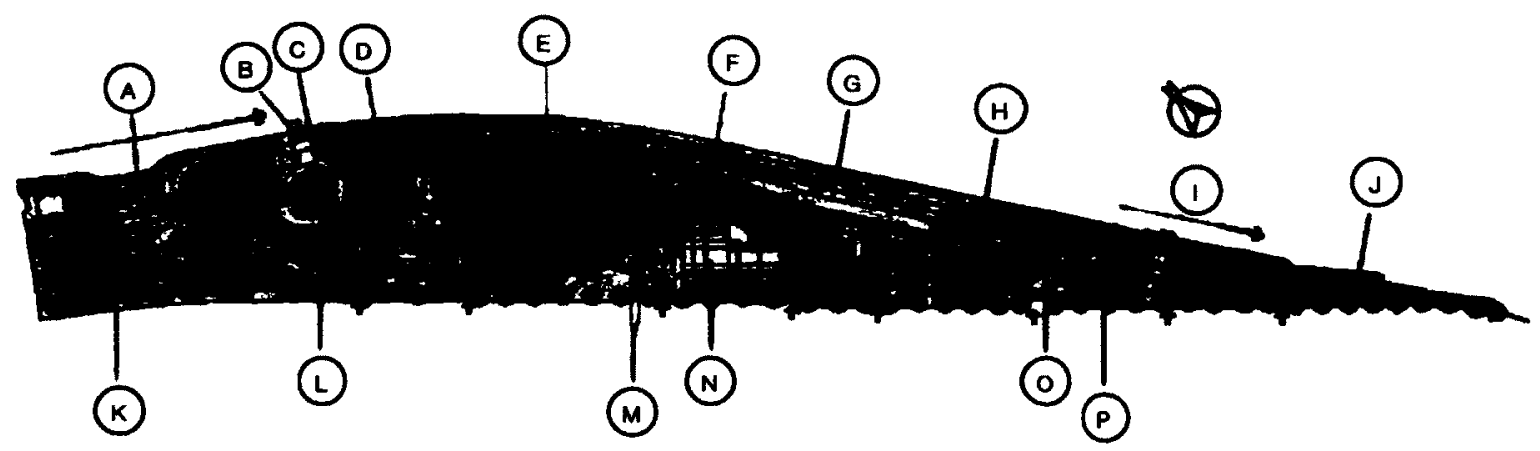

Figura8: Living water Garden, Plan

A) Steps to River; B) Pump House; C) Settling Pond; D) Aeration; E) Fitering Ponds; F) Stream; C) Steps to River; H) Amphitheatre; I) Water Fow; ل) Water Returns to River; K) Natural Wild Area; L) Interactive Environmental Education Centre; M) Fowtorm; M) Greenhouse; 0) Fowform; P) Fountain Recreation.

returned to the rivers from which it came. Effluent water from this system is Considered to be clean enough to drink. ${ }^{52}$ Visitors can walk anywhere in the park for the purpose of learning about water attributes. The park also provides a sanctuary for wildlife. The two associated dead rivers now have a park that provides an oasis of life on their waterfront. This park helps us understand the potential that rivers have for life. Among over a hundred plant species, the park also includes an environmental education centre, underground parking garage and an amphitheater. ${ }^{53}$ There are two places where visitors can walk down to the actual rivers from the park. Seeing the rivers after experiencing the park gives perspective on the difficult effort that goes into cleaning the water that seems so easily polluted. The water treatment ponds have little affect on the rivers' total biology. Visitors how go down to the rivers edge see how much they are still plagued by pollution. ${ }^{54}$

Though here the magnitude of the treatment of water does little to effect

52 The article does not specify to which standards this water is potable, and may not be considered safe to drink in North America.

53 Keepersofthewaters.org,

54 'Yes" Magazine, yesmagazine.org 
the overall biology of the rivers, the landscape provides a stage for recreation and education on water treatment. The systems include plant treatment ponds and pools. The concrete pools, called "Flowforms", developed by John Wilkes, are specially designed to oscillate the water in a way that helps extract impurities from

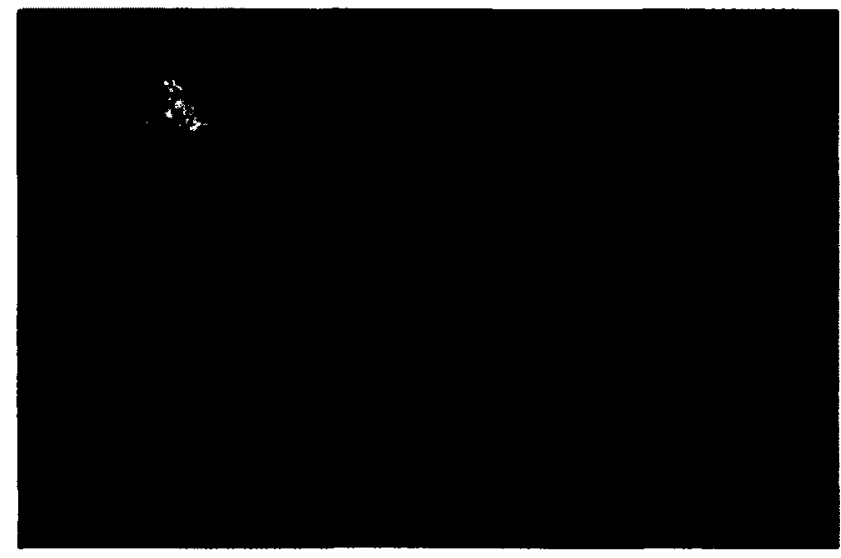

Figure 10: Fountain

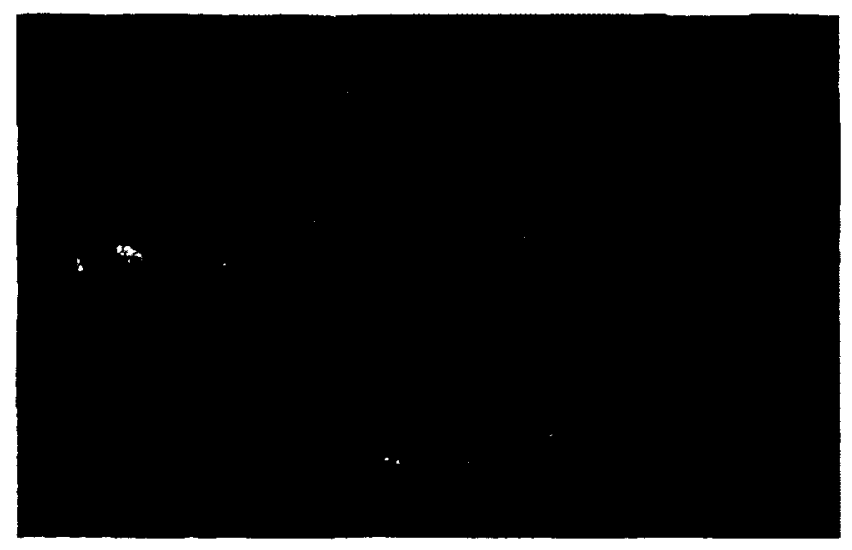

Figure9: Flowtorm

the water. ${ }^{55}$

Wikes is an artist and sculptor who is known for his research on the movement and mood of water. Flowforms are helpful to the water purification systems because they allow the rhythmic movements of water to support animal and plant processes. Wilkes's research first started with an observation of nature, namely the

55 Wikes, Fowtorms, 166. 


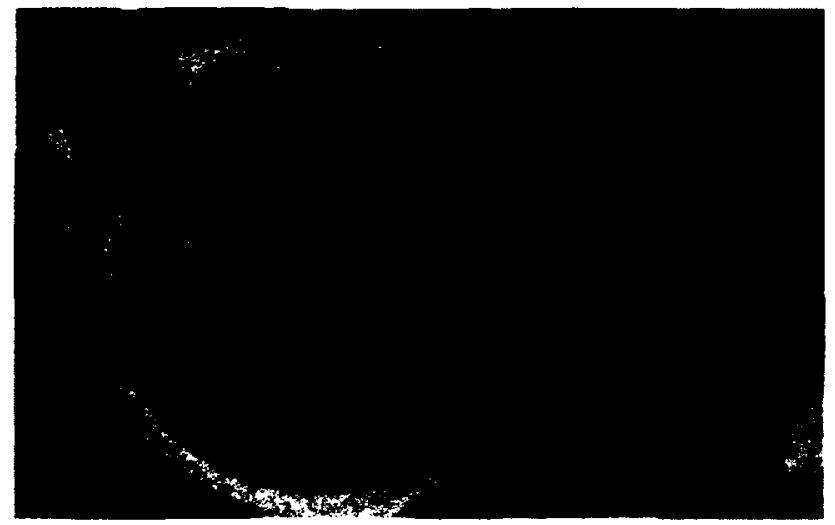

Figure11: Flowtorm

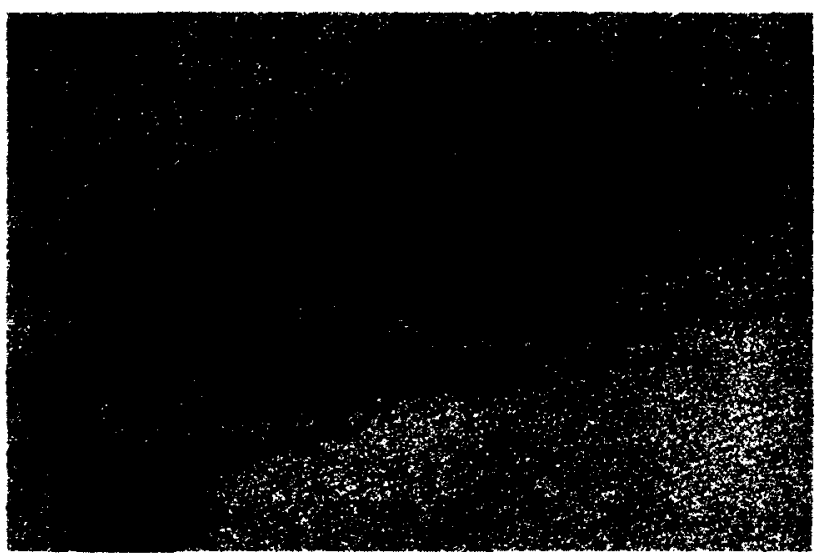

Fioure12 Flowtorm

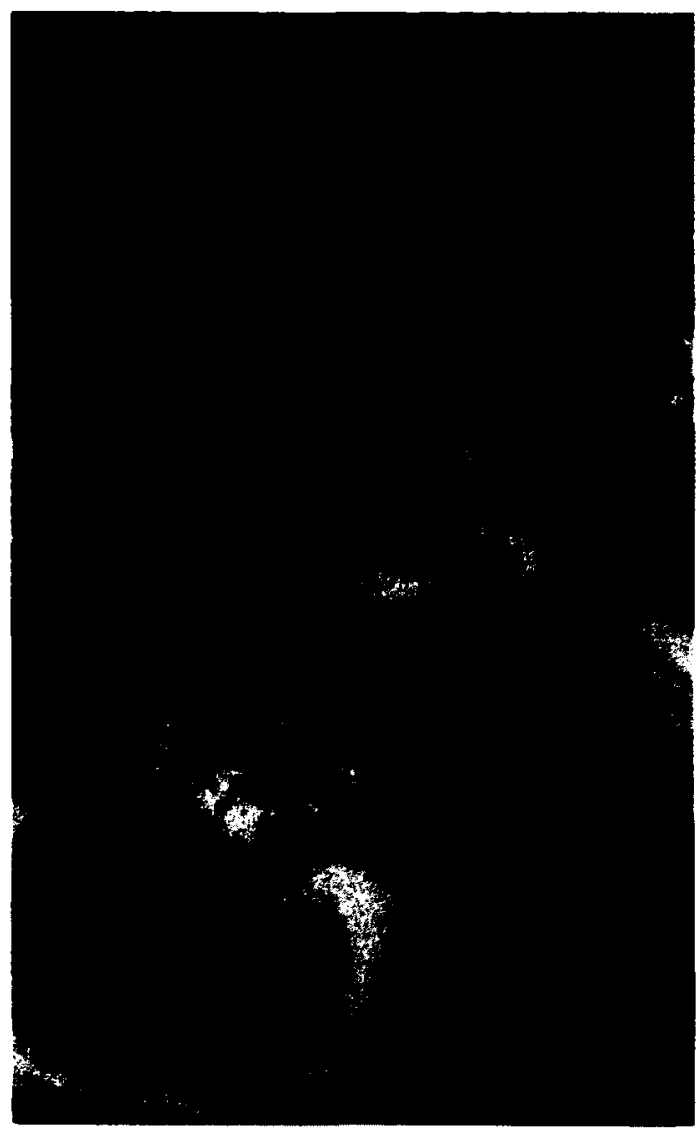

Figurv13: Flowtorm

meander, meaning the "pulse" of the river. "If we observe the streaming of water and closely watch the movements caused by flowing under the influence of gravity, we see that through the slightest resistance, curving vertical forms are generated. Water always tends towards the sphere and, in streaming, towards the vortex." 56 The movements of water flow from left to right and back again. Water melting from a glacier carves these particular back and forth patterns into its icy facades. The movement becomes asymmetrical when the stream of a liquid meets resistance, "it will curl into a curve"57. Water is about balance:

- Water is moved by gravity and also settled by gravity.

- Water changes from cool to warm, is oxygenated to deoxygenated.

56 Wilkes, Fowtorms, 29.

57 Wilkes, Fowtorms, 30. 
- Water moves from clean to polluted, erosion to deposition.

- Channels of liquid move from fixed streams to shifting ones. ${ }^{58}$

As water wants to be in balance with itself, Wilkes is able to create sculptural water sinks that emphasize water's natural tendencies in motion. The result is a beautiful sculpture that both cleans water and creates a sensual experience. Besides water cleaning facilities, Flowforms have also been used for food production as it has been found that the quality of water affects the quality of the produce..$^{59}$ Flowforms have shown that they are beneficial to water and the life that is supported by the treated water, and ultimately to the water treatment process.

Wilkes's sculptures have a beautiful poetry with water; this is something I want the visitors of my park to experience. People will enjoy the water, through its sensual qualities, and as with the Living Water Garden, the proposed design also has an educational element. The Chengdu project does not, however, have an ecological impact on the environment to the rivers of the city. A facility that is actually able to fully clean the rivers to an ecologically "good standing" would not only help the environment but also affect the uses of the waterfronts by citizens of the cities. This is the type of impact I want my project to have as the waterfronts in Ottawa are underused given that they are now frequently too polluted to use.

\subsection{The Omega Institute for Holistic Studies, Rhinebeck, U.S.A.}

The Omega Institute is located in Rhinebeck, New York, along the Hudson River, north of New York City. It is a campus dedicated to help people "bring more meaning and vitality into their lives". ${ }^{80}$ The campus is located on a 195-acre lot

\footnotetext{
58 Wilkes, Flowforms, 31. from Table One.

59 Wilkes, Fowforms, 141.

60 Berkebile, McDowell, Stephen and Lesniewski, Flow, 22.
} 
which is in the countryside of Rhinebeck. The water facility treats five million gallons $\left(18,927.05 \mathrm{~m}^{3}\right)$ of water each year. ${ }^{61}$ It cleans water that has been used for human waste and storm water. This facility uses a natural wetland system to clean water, maintained entirely within one building. It adopts naturally occurring processes known to clean water in order to creating what is known as a living machine. The facility is a building with a surrounding landscaped garden which was previously a parking lot.

"The building is a living building: it harvests its own energy, cleans its water, gives back more than it uses, mimics nature, and embodies its own sense of beauty." 62

This institute promotes the synthesis of architecture and the "eco machine" which can be applied to buildings of any scale. ${ }^{63}$ Its goals are to encourage a new kind of domestic living and thus architecture. It is a campus which is visited by over 20,000 people each year through retreats, workshops and conferences. This institute remains the largest holistic learning center in the United States. ${ }^{64}$ Along with water treatment the building also provides space for yoga and classes for "restoring the human spirit". ${ }^{65}$

What the Institute is lacking is an urban site. It is also not particularly public as the campus is away from the main core of the town. It is a public building but not easily accessible in terms of distance. Only those who can afford to pay and make time to come to this facility can enjoy what is has to offer. Based on the amount of parking provided on campus and its remote location outside of town, it can be assumed that a car is necessary to travel to the campus, hence further

$\begin{array}{ll}61 & \text { Berkebile, McDowell, Stephen and Lesniewski, Flow, } 6 . \\ 62 & \text { Berkebile, McDowell, Stephen and Lesniewski, Flow, } 7 . \\ 63 & \text { Berkebile, McDowell, Stephen and Lesniewski, Flow, } 5 . \\ 64 & \text { Berkebile, McDowell, Stephen and Lesniewski, Flow, } 22 . \\ 65 & \text { Berkebile, McDowell, Stephen and Lesniewski, Flow, } 22 .\end{array}$


Figuro14: Omega Campus 


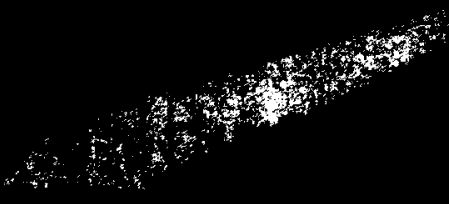

Figure15: Omega

limiting its accessibility to the public. The facility provides much support for the individual, but does not provide public urban space, thus it does not provide opportunities for greater changes in urban lifestyles and ideologies.

I would like my project to have the greatest impact on the greatest number of people. An urban site close to the centre of the city, would have a better chance of affecting more people than a rural one as population densities are higher. Parks 
and green spaces are fewer in the city than in the countryside, thus cities need the parks so that citizens may enjoy outdoor space. The Omega Institute is upstream from New York City, meaning the water it cleans does have an urban impact but it is less evident and has no physical presence in the city other than the water itself. Because the city is so far down stream it is unlikely the general population even knows of the existence of the facility and its beneficial impact on the environment.

The project should, but does not include educational elements for children. A greater impact can be achieved if the next generation is exposed to these issues of pollution so that they are aware of the changes we must make as a society. I want my project to have a meaningful impact on the culture of the city and encourage better care for the environment and public places.

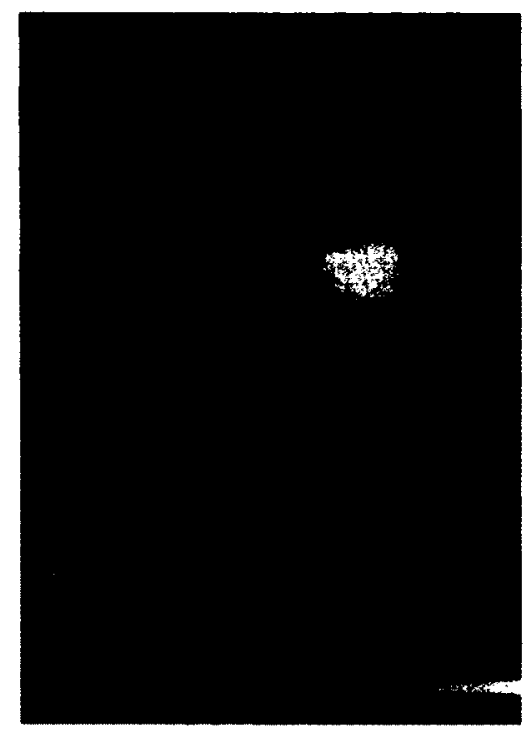

Figure16: Yoga Studio

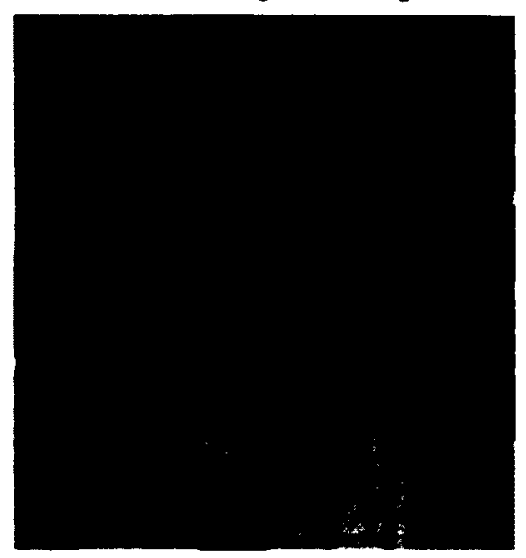

Figure17: Indoor wetland system

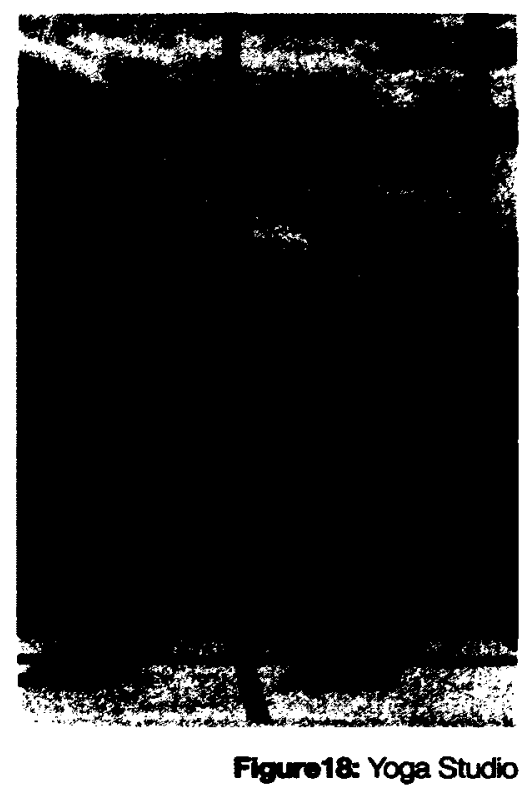




\section{Public Park}

\subsection{Proposal}

In response to issues of water consumption and pollution this thesis will propose the creation of a water treatment facility. This facility will clean water to benefit both the environment and the social urban condition. The mandate is to help reverse the effects of water pollution on one particular waterway within an urban landscape. In the interest of involving the public, the space will provide a landscape intervention that will clean water and also act as a public park. The park will integrate recreation space with education about the water cleaning process. The project will aim to clean the whole of the waterway. Thus, the park will affect public waterfronts along the chosen waterway throughout the city.

\section{Program for Park:}

- Amphitheater

- Public washrooms with change rooms and showers

- $\quad$ Paths to walk, enjoy the new spaces and to learn about water treatment

- Boat Docks

- $\quad$ Sitting areas

- $\quad$ Bike racks

- $\quad$ Spaces for recreation

\subsection{Design Aspirations}

Visitors need to be able to easily understand water treatment processes, such as water cleansing. Human experience needs to include more than just the sight of the water system. The park will include the sensual experience of water 
through some of the following ways:

Smell: water applied to different materials has a unique smell (i.e.: wet earth has a particular smell different from the smell of wet plants).

Touch: guests will walk through areas of mist and water drops. Ponds at the end of the system containing cleaned water will invite people to touch it.

- $\quad$ Mist

- $\quad$ Ponds

- Icicles

Taste: water fountains, providing the cleaned water, will be available in the park.

Sound: when water is flowing more rapidly the architecture will amplify the sound of water oscillation.

- Drips

- Trickle

- Splash

- Falls

The waters and the park visitors will move together. When water movement is slow the park's spaces will be places to sit. When water is moving more rapidly, people will move in more narrow spaces with stairs (steps being a more rapid way to travel versus a ramp). 


\section{Site}

\subsection{The Experimental Farm, Ottawa}

The Experimental Farm is a historic site located in the city of Ottawa. The Farm was originally started in 1886 , by a group of politicians who realized the need for a Federally owned agricultural area. This farm aimed to provide research and knowledge for Canadian farmers who at the time were getting their knowledge merely from friends and family. ${ }^{66}$ Ottawa's Farm was declared a historic site in 1988. Since then, the farm continues to host tours for visitors and school groups. ${ }^{87}$ Some of the Farm's research include studies involving genetics and honey bees. The Farm has three main zones within its premises: the planted field for crops and livestock, the botanical gardens, which is a public landscaped garden, and the building campus. The buildings are barns for live stock, green houses, the agricultural museum, administrative buildings and other utility buildings necessary for running a farm. ${ }^{88}$

I chose this site for my proposal because of its location and relevance to the history of Ottawa and because it is located beside the Rideau Canal, which is an important symbolic waterway of Ottawa. The Farm has an urban location, making it a localized resource because it is with-in the city, not on the outskirts of the city. It was also a place for research and learning about agriculture and horticulture. The Farm is able to provide many of the elements needed for the water treatment garden. It has a lot of land that is unused close to the Canal. The Canal is downstream from Mooney's Bay, which is a known polluted beach in Ottawa. The Canal also has a heavily controlled flow which will allow the water treatment facility to clean all the water that passes through it. In my original plan the water that was

66 Smith, Ottawa's Farm, 9.

67 Smith, Ottawas Farm, 124.

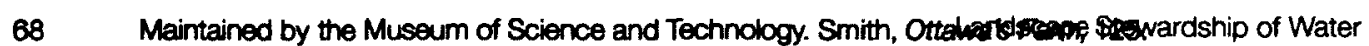


(อ) 9

(อ)

Figure19:

Experimental farm, Ottawa; a) Planted Fields; b) Administrative Buildings; and c) Botanical Gardens

treated would be used for irrigation on the Farm. However, it was later decided that given the significance of the polluted Canal of Ottawa, it would be a more effective statement to the public to put the clean water back into the Canal, making it a swimmable waterway. While the Canal is already used to skate in the winter, it will now be accessible in the summer as a swimming tributary as well. 


\section{Public Park and Water Treatment}

\subsection{The Proposed Water Treatment}

Informetion in the following chapter was taken from: Water Environment Foderation. Netural eyctems for Wastowater Treatiment Third Ed: Manuel of practice No, FD-16. Alaxendrla: Water Emironment Federation. 2010.

Mochanical filter:

there are three main methods to clean water:

chemical, biological and mechanical. Chemicals are added to counter act, breakdown, absorb and/or neutralize impurities in the water. Biological breakdown and/or absorb impurities using organic materials. Mechanical is a physical barrier that does not allow impurities to pass through.
The system will use a natural plants method to clean the water. Water will go through a two-segment treatment, with duckweed as the primary plant for water treatment, and a secondary treatment will be via water hyacinth. This system will remove or reduce heavy metals, toxins, lower bacteria (e-coli) to healthy levels, reduce algae content, reduce the organic materials and suspended solids in the Canal's existing water. The goal is to provide stable bacteria levels for regular public swimming, as well as an ecologically fertile environment for wildlife.

Duckweed removes a small portion of the total suspended solids (TSS) from water using its roots as a mechanical filter. Nitrogen, phosphorus, millimolar amounts of copper and zinc are partially removed from the water by absorption through duckweed. This plant covers the water with a mat of foliage which blocks all light to the water, thus killing algae. Bacteria and parasites that survive on algae will die due to lack of a food source. However, the water flow must be slow, so duckweed is the most time consuming treatment in this system. Duckweed is also easily disturbed and a gridded barrier must be used on the surface of the water to compartmentalize it. The barrier will 
Efficem, Water flowing out of the water treatment pond

Organic loading rate is the amount of organic waste being taking out, hydraulic loading rate is how fast the system is working.

\section{Detention timo: the} time period in which the water must circulated in a given area. prevent the wind from pushing the duckweed into the corners of the ponds, and maintain an even distribution of the plant. Effluent water must go to a ten day holding tank before proceeding to the hyacinth treatment. This is determined using the organic and hydraulic loading rates.

Hyacinth removes a small portion of TSS and dissolved nitrogen. Heavy metals and toxins are partially removed in the sludge layer and partially removed in the roots layer.

Both of the above plants are considered to be invasive; however, neither plant can survive in temperatures below $5^{\circ} \mathrm{C}$. Ottawa's harsh winters prevent the plants from becoming an environmental nuisance. The water plants will need a winter green house to keep a stock of plants for the following season.

Odours can be an issue with these systems. However, recycling the water can reduce the odours and makes the whole system run faster. Such a process requires an electric pump at the end of each pond to distribute effluent water back into the pond. One of the goals of this project is to use technology in a minimal way, therefore, this system will not recycle the water. A recycling system is able to process water faster, but requires a pump to re-circulate the water therefore using more energy. Not having a pump to recycle the water will require the creation of more ponds on site with a longer detention time in each pond. In this case odours are a small factor given this system is treating Canal water and not raw sewage. As long as the impurities that are separated from the water are harvested regularly, odour 
Three to twelve moths: this the personal experience of author.

Hoeny motal treetmont, such as, absorption, sedimentation, chemical precipitation, and plant intake.

Fertilizer: This meets U.S. EPA 503 pathogen and metals equipment for ctass A compost.

Boom: Large mechanical am to remove plant mater. should be no worse than what exists now at the Canal.

Regularly harvesting both plants and the sludge sediment must be done to remove the impurities from the water. The plants must be put in a detoxification tank where they can release any chemicals they absorbed from the water. The plants are then laid out in the sun to dry for five days. When moisture content is reduced to sixty percent they can be ground into a pulp. Minimizing moisture content reduces plant volume after which they can be composted. Plant matter that has been biodegrading for three to twelve months can be used as fertilizer for the Experimental Farm. The sludge must be treated for heavy metals and toxins before it to can be put into compost and later used as fertilizer. For harvesting, it is common for staff to use a truck with a boom attached to it. Using a truck contradicts the landscape intent of making as little impact as possible on the environment. Thus, the design will propose a manually operated boom. To maintain efficiency of the boom, the ponds containing plants will all have to be no more that two and a half metres wide (eight feet).

Mosquitoes like to reproduce in warm stagnant and slow moving waters. This makes the treatment ponds ideal for mosquito larvae. In order to keep the mosquito population under control, fish that feed on the larvae, as well as other bugs, will be stocked in the treatment ponds. These fish, common name mosquito fish (gambusia affinis), eat the mosquito larva as well as other bugs that may try to inhabit the ponds. 
Aerebed: a process that add air into water.

Non-eeruted: does not add air to the water.
One of the buildings of the new landscape will be needed for the compost facilities and a greenhouse. The greenhouse is where a portion of the plants will be stored over the winter months.

There is also a choice that must be made between an aerated and non-aerated system. Power input for a non-aerated system is lower, and has less odours and mosquitoes than an aerated systems. Aerated systems clean more water at a faster rate than non-aerated. In the interest of less mechanical systems and low

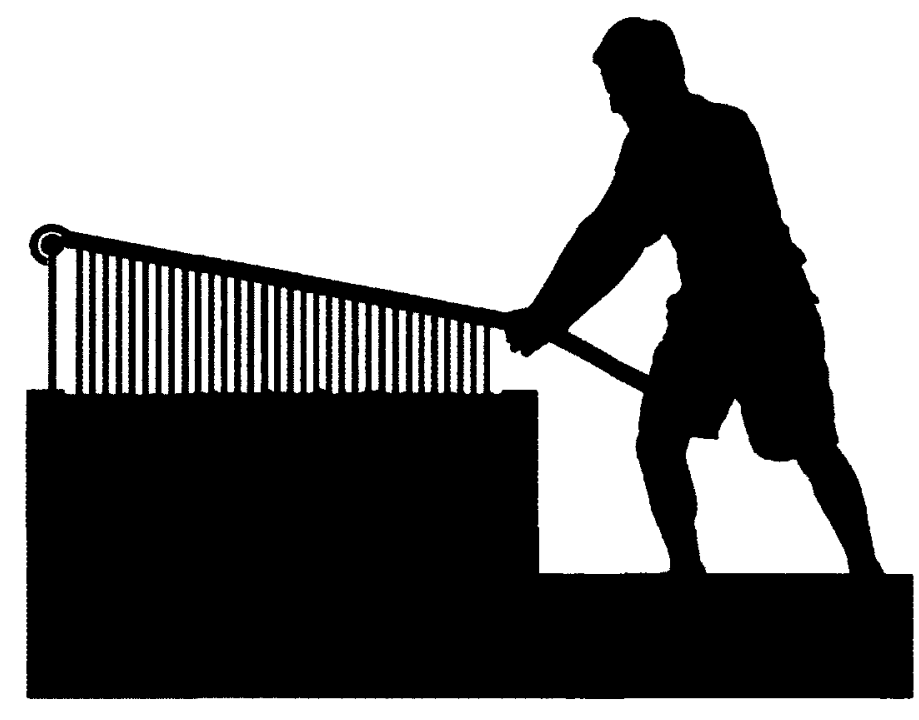

Figure20: Mechanical Boom

energy input, this system will use a non-aerated system.

Before water is put back into the Canal it will travel through a series of oscillation pools. The pools will not only clean the water further but also fulfill atmospheric goals mandated in the design intent. Sound is the primary sensual focus of this element in treatment. 
Drinking Water: A tertiary treatment system is required to make the water potable. The primary and secondary treatments are sufficient for putting water back into the environment. A third system is needed to eliminate bacteria and pathogens in the water. An ultra violet light is the most commonly used method to kill bacteria in water.

\subsection{Program for a Water Treatment Facility in Ottawa}

The site will be in the Arboretum section of the Experimental Farm. The treatment ponds and gardens will occupy $20,000 \mathrm{~m}^{2}$ of land on the Arboretum. The site will channel water from the Rideau Canal and irrigate it through a series of ponds, set up for water treatment. The water will be cleaned in a visible way to inform the public of what is involved and why it is important. In turn, the goal is to encourage our culture to take better care of our resources. The ponds will take up an estimated $5,000 \mathrm{~m}^{2}$ not including access routes and walkways to the ponds.

Pond dimensions are as follows: width, as specified above, is $2.43 \mathrm{~m}$; depth is a shallow $0.5 \mathrm{~m}$ for duckweed and $0.85 \mathrm{~m}$ for hyacinth. ${ }^{90}$ Length can range between 6 and $9 \mathrm{~m}$. Each system will require a minimum of 6 ponds each, plus ten detention tank for effluent duckweed water.

Wastewater treatment ponds: $30,000 \mathrm{~m}^{2}$ (using table 8.2) $480 \mathrm{~m}^{3}$ per day using 2 hectors of land leaving 1 hectors of land for public park and access ways to maintain system. Ponds will be terraced along a slope using a "plug flow" system. ${ }^{70}$ Plug flow assumes the velocity of the fluid is consistent through the cross section of the pipe or pond, it assumes there is no boundary between fluids.

69 These dimensions where calculated using an existing water treatment plant in the United States. Water Environment Federation. Natural systems for Wastewater Treatment Third Ed.: Manual of practice No, FD-16. Alexandria: Water Environment Federation. 2010.

70 Calculations in Chapter 8.Water Environment Federation. Natural systems for Wastewater Treatment Third Ed.: Manual of practice No, FD-16. Alexandria: Water Environment Federation. 2010. 
The treatment ponds will clean $33,360 \mathrm{~m}^{3}$ of water per week. As potable water, this could supply water to 4,582 Ottawa homes on a weekly basis. Homes are assumed to have an average of four occupants per residence. ${ }^{71}$ Water usage includes household purposes such as, washing, food preparation, and bathing.

However, the clean water will be placed back into the Canal. This will make the Canal water throughout the city clean enough to swim in during the summer months. As there are few public beaches in Ottawa that are reliably safe to swim in, the Canal can then become a new public waterfront that is continually safe to swim in, therefore, establishing a new trust between the water and the public opinion of that water. This will affect public spaces next to the Canal throughout the city, while remaining open for boats to travel. The goal is that the Canal will become as public in the summer as it currently is during the winter when it is a skating rink.

- $\quad$ Public park area: $15,000 \mathrm{~m}^{2}$

- Indoor wastewater treatment/ winter greenhouse

- $\quad$ Research Lab

- $\quad$ Compost and sludge treatment

71 This is based on The Domestic Water Consumption Report (1999) of National Resources Canada. See calculations in Section 8.5 Water Environment Federation. Natural systems for Wastewater Treatment Third Ed.: Manual of practice No, FD-16. Alexandria: Water Environment Federation. 2010. 


\section{Water System Calculations}

Calculations done with Chris Alexander BSc Mechanical Engineering, 1992.

\subsection{Vocabulary}

- Small " $\quad$ " is Days

- Primary: Step one in treatment

- Secondary: Step two in treatment

- Tertiary: Step three in treatment; this step not always needed.

- TKN: Toxic

- TSS: Total suspended solids

- BOS: biochemical oxygen demand

- ha: hector

- ac: acre

- RDS: Rotary Drum Screen

- RDF: Rotary Disk Filter

- $\mathrm{Mg} / \mathrm{L}$ : milligrams per liter - influent concentration

- $\quad$ Aerated: to add air

\subsection{Primary Treatment Using Duckweed}

Effluent: [mg/l]

BOD 10-15\} Input to Secondary Hyacinth

TSS 10-15] Input to Secondary Hyacinth

Secondary Influent (Hyacinth):

$15 \mathrm{mg} / \mathrm{L}=0.015 \mathrm{~g} / \mathrm{L} \quad=0.00095 \mathrm{~kg} / \mathrm{L}$ 


$$
\begin{aligned}
& =1.5 \mathrm{~kg} / 100,000 \mathrm{~L} \\
& =75 \mathrm{~kg} / 5,000,000 \mathrm{~L} \\
& 75 \mathrm{~kg} / 5000 \mathrm{~m}^{3}
\end{aligned}
$$

\section{Assume Primary Effluent BOD/TSS:}

$75 \mathrm{~kg} / 5000 \mathrm{~m}^{3}$

- Becomes $75 \mathrm{~kg}$ organic loading rate per day

- Within bound of $44-110 \mathrm{~kg} / \mathrm{ha} \cdot \mathrm{d}$

$75 \mathrm{~kg} / \mathrm{ha} \cdot \mathrm{d} \quad$ - input means $500 \mathrm{~m}^{3} /$ day

- Cross section Area $=5.4375 \mathrm{~m}$

- Total height of ponds $=919.54 \mathrm{~m}$

$=920 \mathrm{~m}$

Secondary Treatment using Hyacinth:

Site: Topography:

- $\quad$ Landslides must be minimized

Soils:

- Slowly permeable $(15 \mathrm{~mm} / \mathrm{h})$ surface soils or subsurface layers desirable

- Basins could be constructed of clay or synthetic liners

Climate:

- Water temperature of $10^{\circ} \mathrm{C}$ tolerated if air temperature is $>5^{\circ} \mathrm{C}-10^{\circ} \mathrm{C}$ 
Pretreatment:

- Required

- Using duckweed system

- 4-6 points (entry channels) with play flow pond (for faster reaction and less odours)

\subsection{Hyacinth Detention Time}

- Depends on organic and hydraulic loading rate

- $\quad$ Organic is most important

Water Depth:

- Vertical mixing for plant root contact (bacterial involvement)

- $\quad$ Non-aerated $-0.45-0.75 m$

- $\quad$ Outlet structure designed so that operating depth can be varied

Organic Loading Rate: Aerated:

- BOD: $65-500 \mathrm{~kg} / \mathrm{ha} \cdot \mathrm{d}$

- Odours Common at loadings greater than $110 \mathrm{~kg} / \mathrm{ha} \cdot \mathrm{d}$

- Odours possible at lower loading if sulfate contamination $>50 \mathrm{mg} / \mathrm{L}$

Non-Aerated:

- $\quad 44-110 \mathrm{~kg} / \mathrm{ha} \cdot \mathrm{d}$

- Defines upper bound; see odours above

Hydraulic Loading Rate:

- Volume of wastewater applied per day divided by surface area of system 
- $\quad$ Secondary treatment $(B O D+T S S<30 \mathrm{mg} / \mathrm{L})$ non-aerated $375-660 \mathrm{~m}^{3} / \mathrm{ha} \cdot \mathrm{d}$

Controlling Mosquitoes:

- $\quad$ Stock pounds with mosquito fish

- Reduce organic loading to maintain aerobic conditions (oxygen levels)

- $\quad$ Frequent plant harvesting

- Water spraying in evening hours

- $\quad$ Prevents mosquito ova position (cannot lay their eggs)

Plant Harvesting:

- Must have machinery access to ponds (boom truck- has a long arm, in this case a manual operated boom will be designed)

- $\quad$ Composted on site

- $\quad$ Chopped using tub grinder and spread thin layer ${ }^{72}$ to reduce moisture content.

- After 5 days when moisture content reaches $60 \%$ formed into piles for composting

- Volume reduced $99 \%$ (avg.)

- $\quad$ Meets U.S. EPA 503 pathogen and metals equipments for class A compost (WCPH and EOA, 1996) Equivalent Canadian Regulations

\subsection{Design Parameters: Secondary Water Hyacinth - Non Aer- obic}

- Hyacinth Power input for non-aerated is lower and has less odours and mosquito population than aerated systems ${ }^{73}$

72 Water Environment Federation. Natural systems for Wastewater Treatment Third Ed, Table 8.16. 369.

73 Water Environment Federation. Natural systems for Wastewater Treatment Third Ed, Table 8.5 and Section 2.1.1 
- $\quad$ Step feed with effluent recycle (6+ point of injection)

- Variable height outlet

- $\quad 0.45-0.75$ water depth (make ponds $0.85 \mathrm{~m}$ deep)

- $\quad 44-660 \mathrm{~kg} / \mathrm{ha} \cdot \mathrm{d}$ organic loading rate

- $\quad 375-660 \mathrm{~m}^{3} / \mathrm{ha} \cdot \mathrm{d}$ hydraulic loading rate

- $\quad$ Temperature requirements for function implies system shut down beginning of fall

- Soil testing required for ponds

- Design around kid slide on sloped surface

- $\quad$ Ponds are flute bottom, $45^{\circ}$ walls trapezoidal cross-section

Use to calculate volume of water sitting

- $\quad$ Channel (pond) width 20-30 ft

- Max influent BOD

$130-180 \mathrm{mg} / \mathrm{L}$

- Detention time: 10-30 Days

Trough Calculation:

$$
\begin{aligned}
A & =1 / 2 h\left(w_{1}+w_{2}\right) \\
& =0.75 / 2(8+6.5) \\
& =5.4375 \mathrm{~m}^{2} \\
w_{1} & =8 \mathrm{~m} \\
w_{2} & =8-2 \times 0.75 \\
& =6.5 \\
h & =0.75 \mathrm{~m}
\end{aligned}
$$




\subsection{Domestic Water Consumption for Ottawa, Canada}

Ottawa consumes between $0.160-0.320 \mathrm{~m}^{3} /$ per person/per day ${ }^{74}$

$0.160+0.32$

$=0.26 \mathrm{~m}^{3} /$ average person/day

$0.26 \cdot 7$ (days per weeks)

$=1.82$

$1.82 \cdot 4$

$=7.28$ /family of four/week

Total estimated clean water produce by water treatment park: $33,360 \mathrm{~m}^{3}$

$33,360 / 7.28$

$=4,582$ families of four/week

74 Natural Resources Canada, unw.nrcan.gc.ca. 


\subsection{The Experimental Farm, Maps and Images}

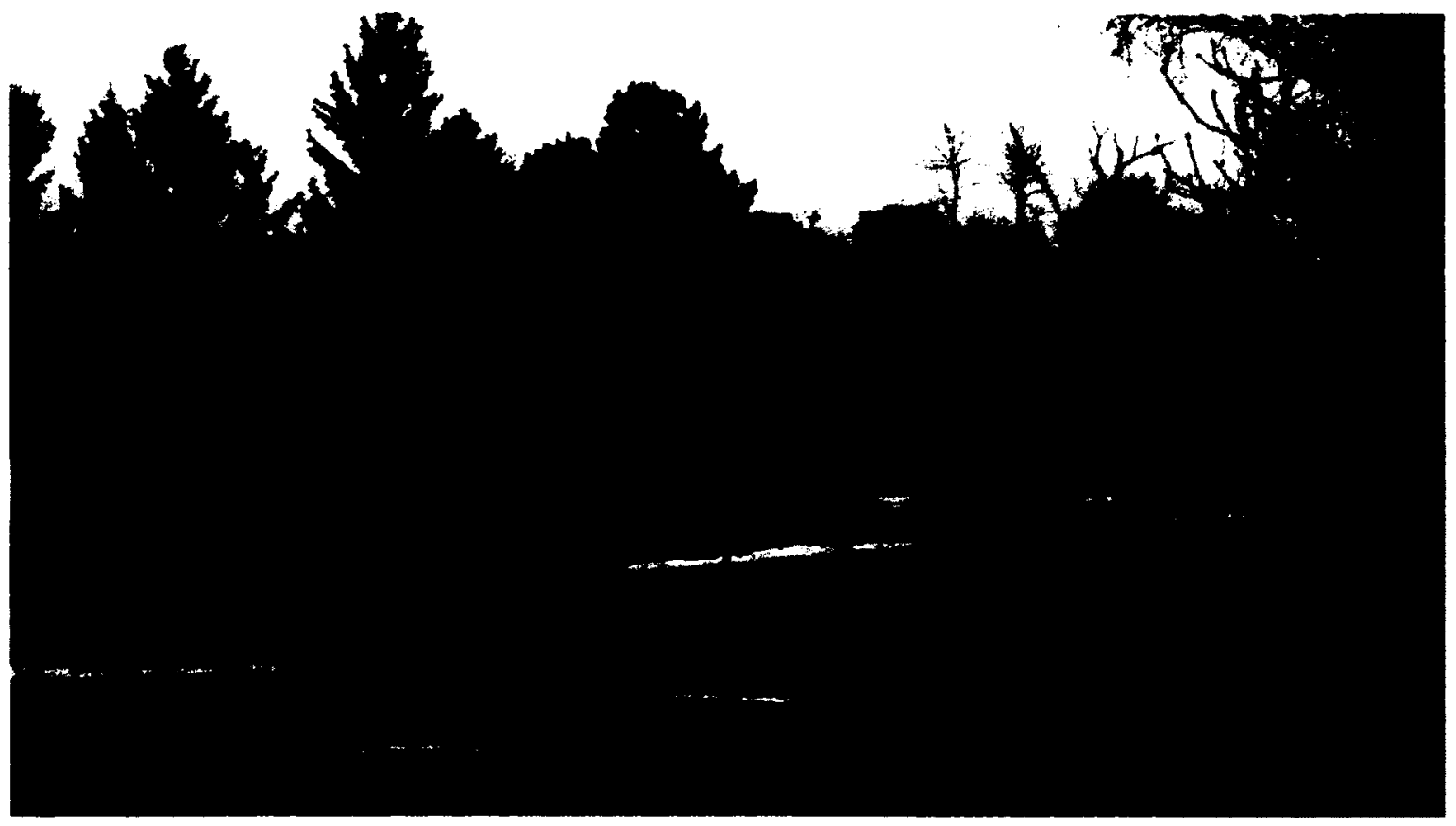

Figure21: Arboretum, Parking lot

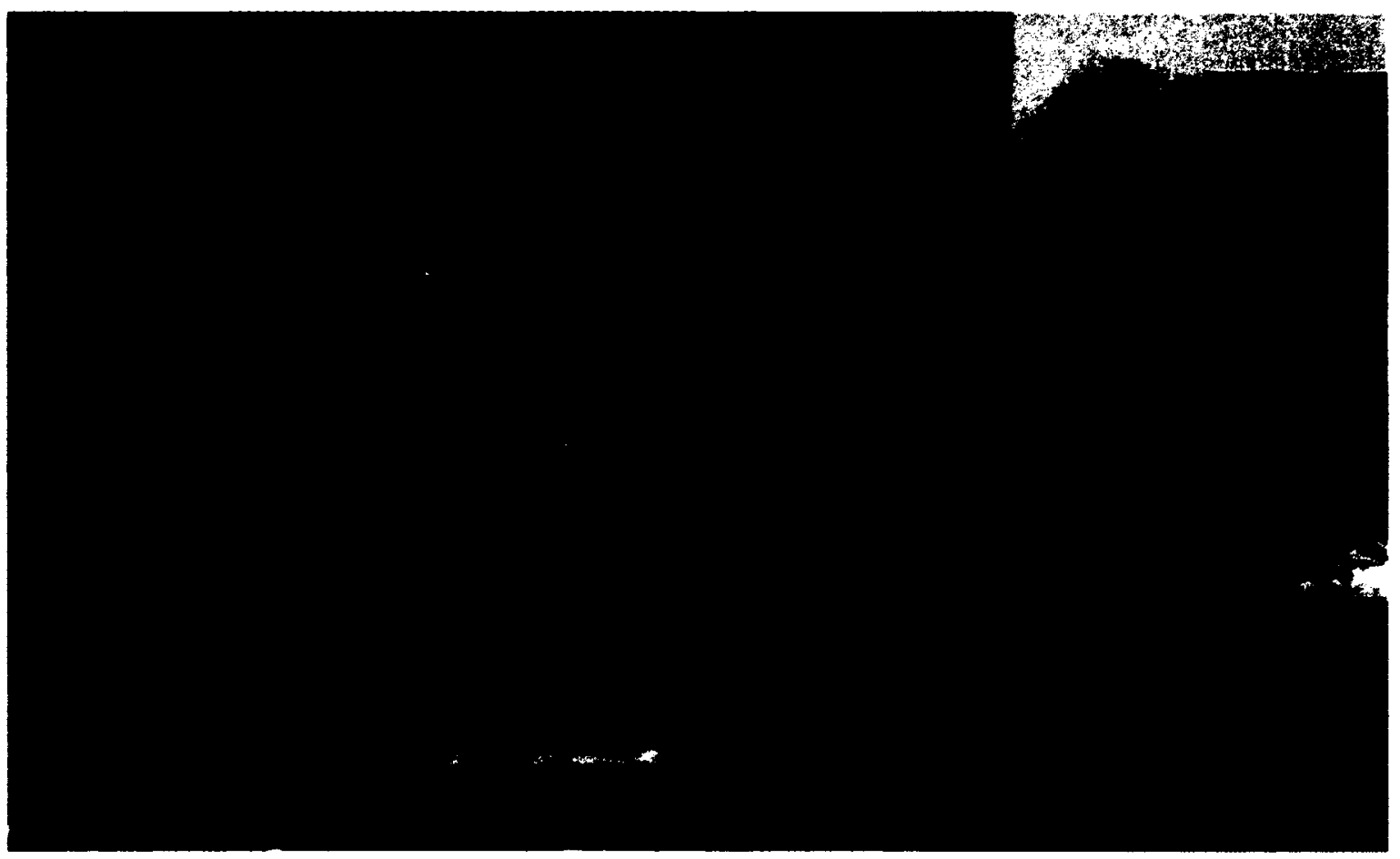

Fgurees: Hartwells Locks 


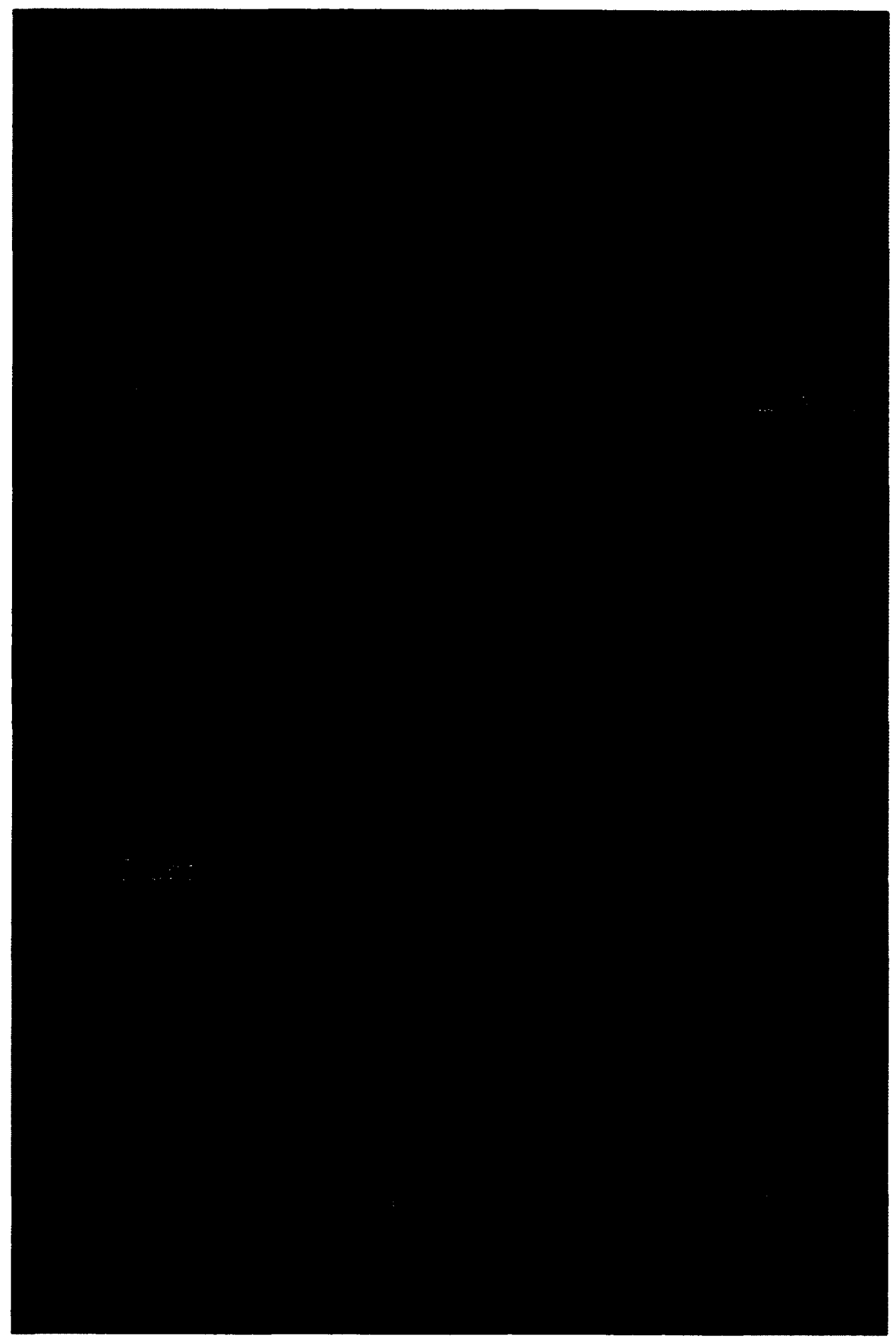

Floure2s: Site Zoning 


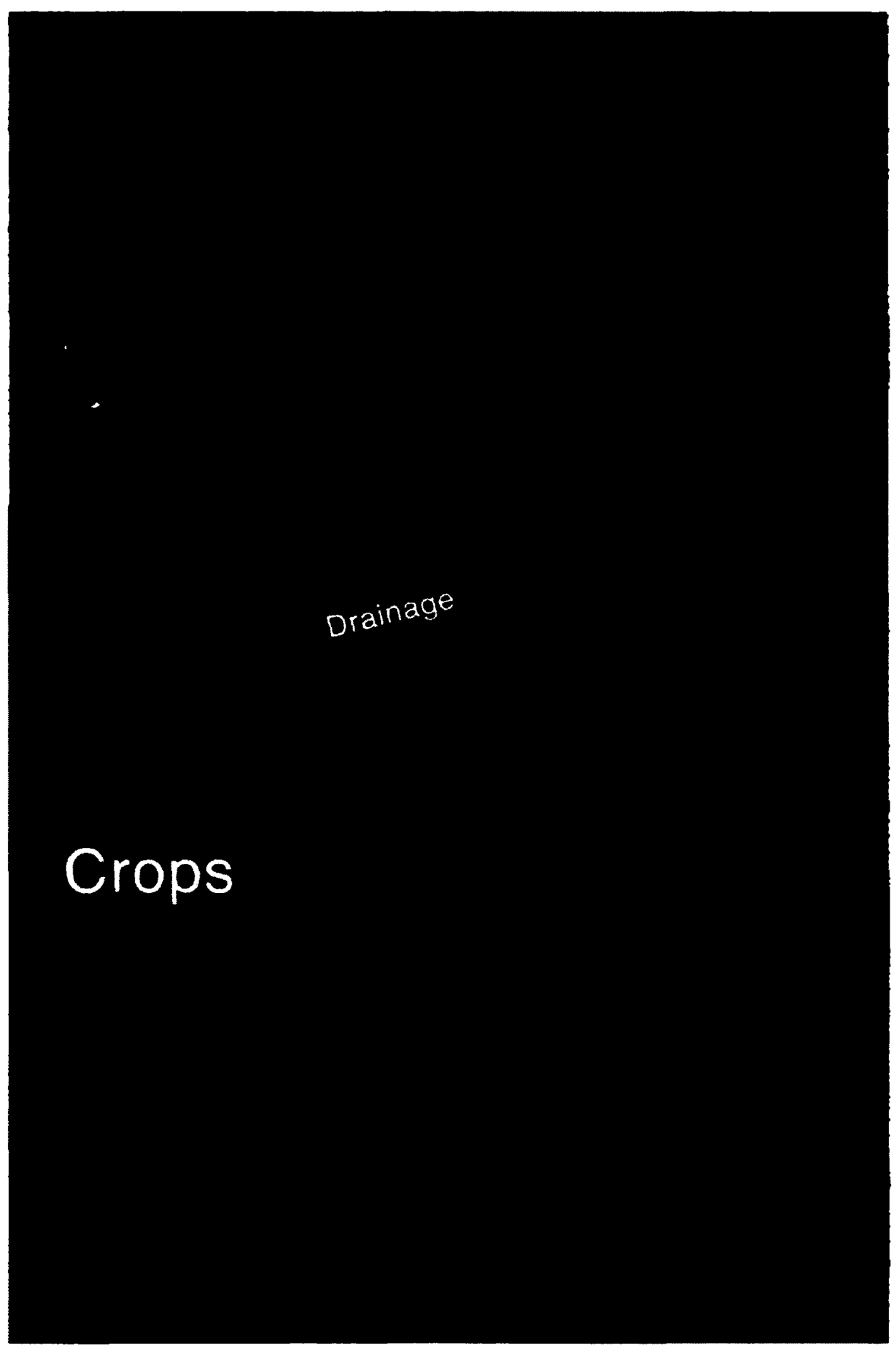

Floure24: Site Topography 
Private Roads and Access Routes

Public Foads

Bike Paths

Figure.20: Public and Private Roads including Bike Paths 


\section{Silet}

Site 3

site 2

Figure2e: Potential Site Choices 


\subsection{Site Choices}

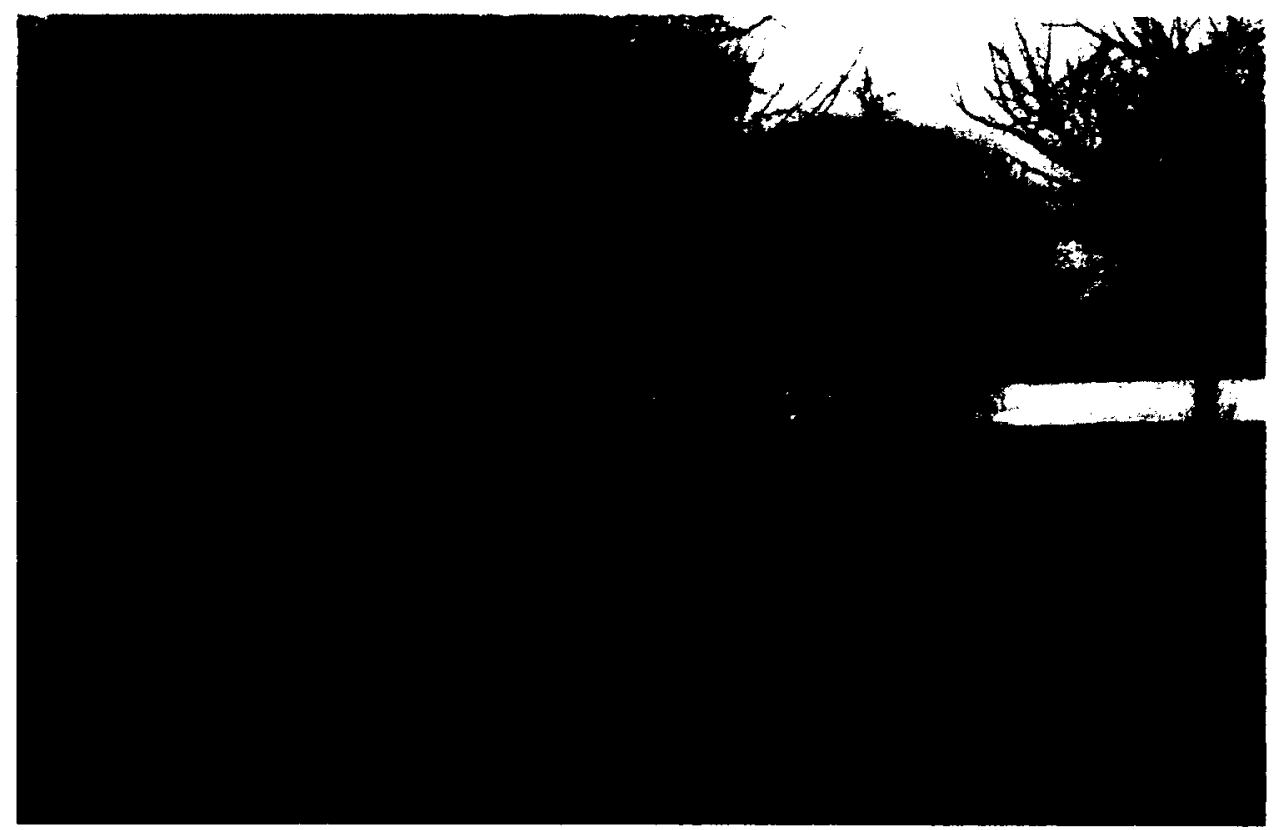

Figure27: Site No. 1

Potential site No. 1, has wooded and open fields with paths and trails connecting to the Canal bike paths. The site already contains the botanical gardens and beehives for the Farm. This site is already landscaped;

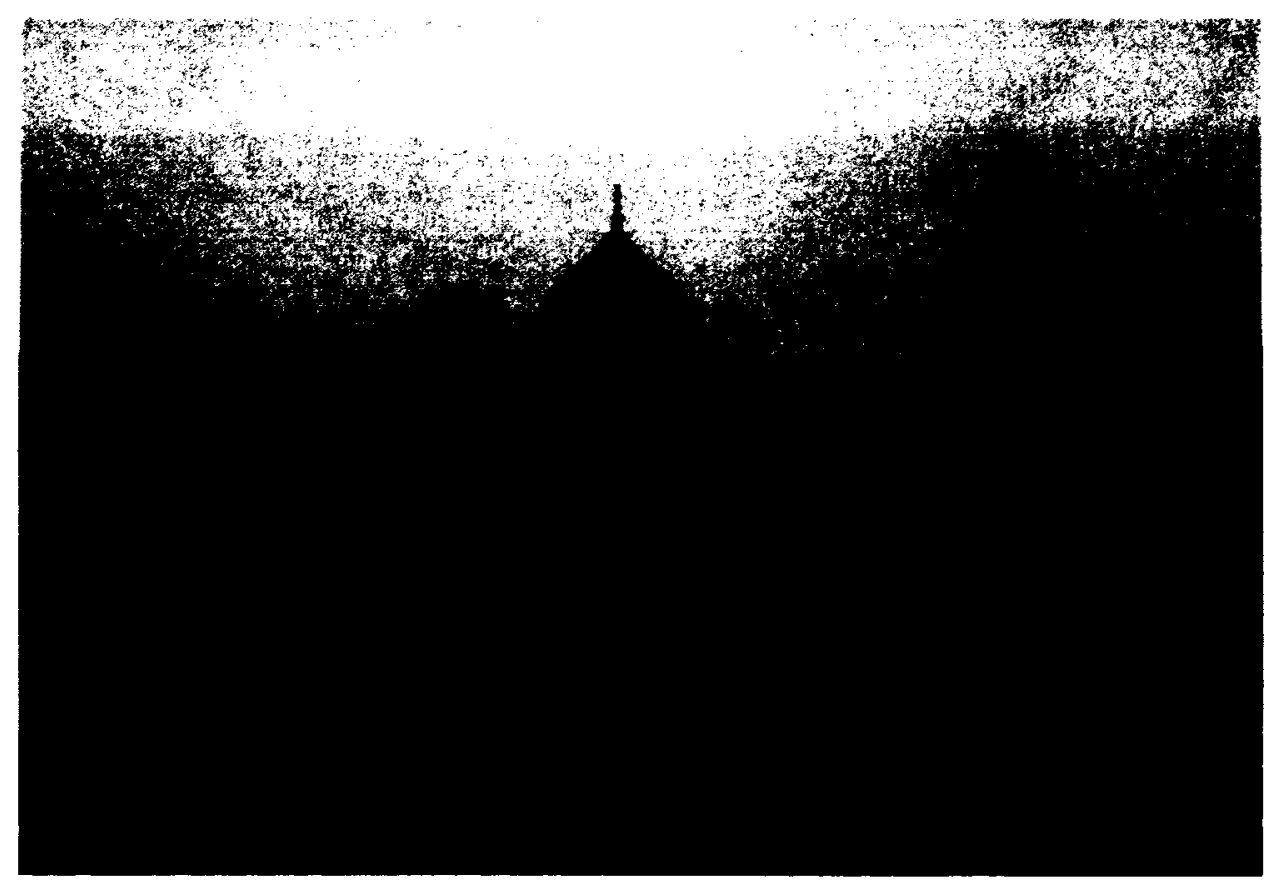

Figureege Site No. 2 
it would be counter-productive to remove a successful public garden only to replace it with another. Therefore this site was not selected for the water treatment centre.

Potential site No. 2, has a large portion of vacant land but does not have good topographical variance. If this site where chosen, mechanical pumping would be required to move the water through the treatment sys-

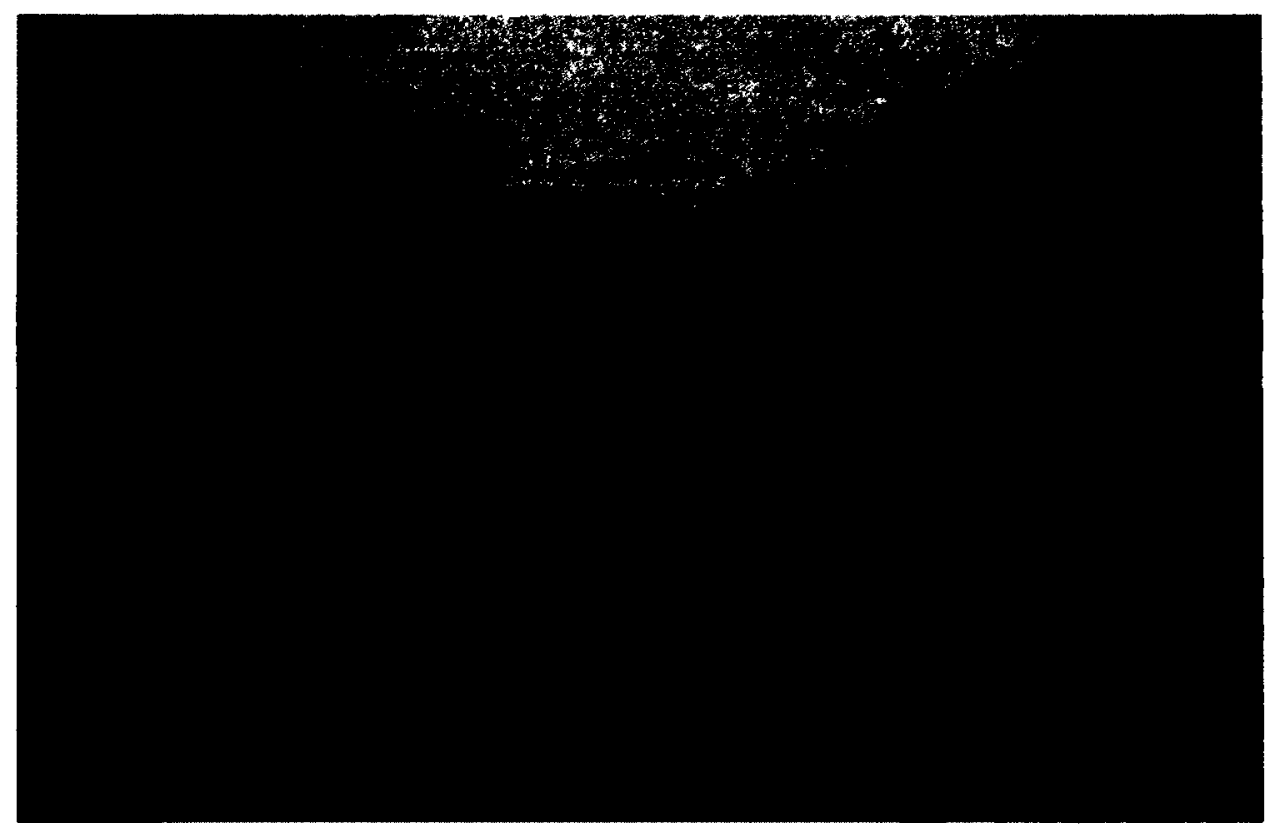

Floureas: Site No. 3

tem. However, this site is too close to the residential subdivisions, office and spiritual buildings.

Potential site No. 3, engages the crossroads between Carleton University's paths and the Canal's bike paths. The site includes the locks, which have a three metre topographical height difference. The difference in height makes this an ideal site for water movement powered by gravity. The site is primarily vacant, and the few exceptions are the historic buildings associated with the locks and the boating docks. This site is close enough to 
the botanical gardens to be able to connect and act as an extension of the existing park. The site has some historical buildings which will need to be incorporate into the design, with preservation of the structures in mind.

Based on these analyses the best choice for the water treatment facility and park, is site No. 3. It has a significant amount of underused space with a substantial topographical drop that can be used to channel the water. It is a crossroads for many students traveling to Carleton University, boaters, and cyclist to name a few. Right beside a bus stop, these factors identify it as a place accessible to a socially and economically diverse constituency, with potentiality for more. 
Water Treatment Sequence

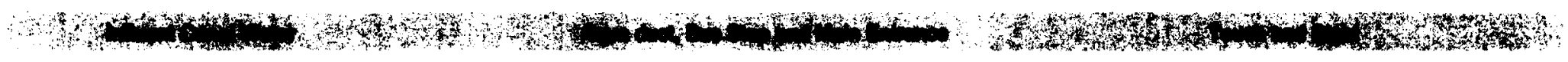
Primary Troatmont: Duckweod Amphttheatro; Slower more organized Clrculation

Sight

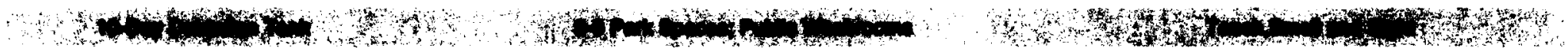

Wot Land Graceses

Marks Major Topographical Drop

Smoll

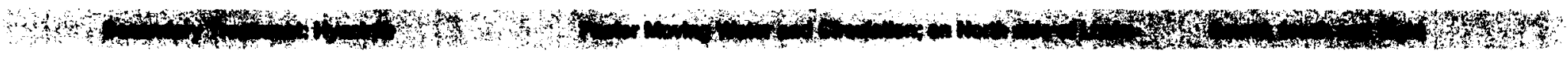

"Flowtorm"

Water SInk

Sound, touch and Bight

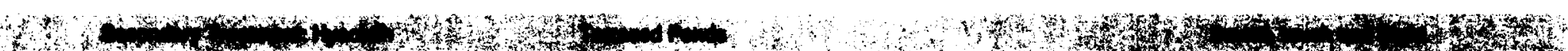

"Flowtorm"

Water Sink

Sound, touch and 8ight

Figures0: Water Treatment with Sensual Experiences 


\subsection{Design}

The arrangement of the site was based on the organizations of the fields on the Experimental Farm. Figure 32 and 33 illustrate the major division lines between the crop fields and extends them over the Arboretum. Crop fields are set up to receive the most sunlight which makes it an ideal way to organize a garden. There is also a natural ordering system made by the topography of the site, largely carved by water erosion. The grid system of the Farm crops and the curvilinear system of the site are the two major ordering systems for the design configuration (Figure 34). The grid sets up the orientation of the buildings and gardens. The topography indicates where the ponds can be placed for natural unpowered flow to occur.

As noted, the goal was to reduce the power requirements as much as possible, and specifically to eliminate the pumping of water into the cleansing ponds.

A height difference between each pond was created so that gravity will power the

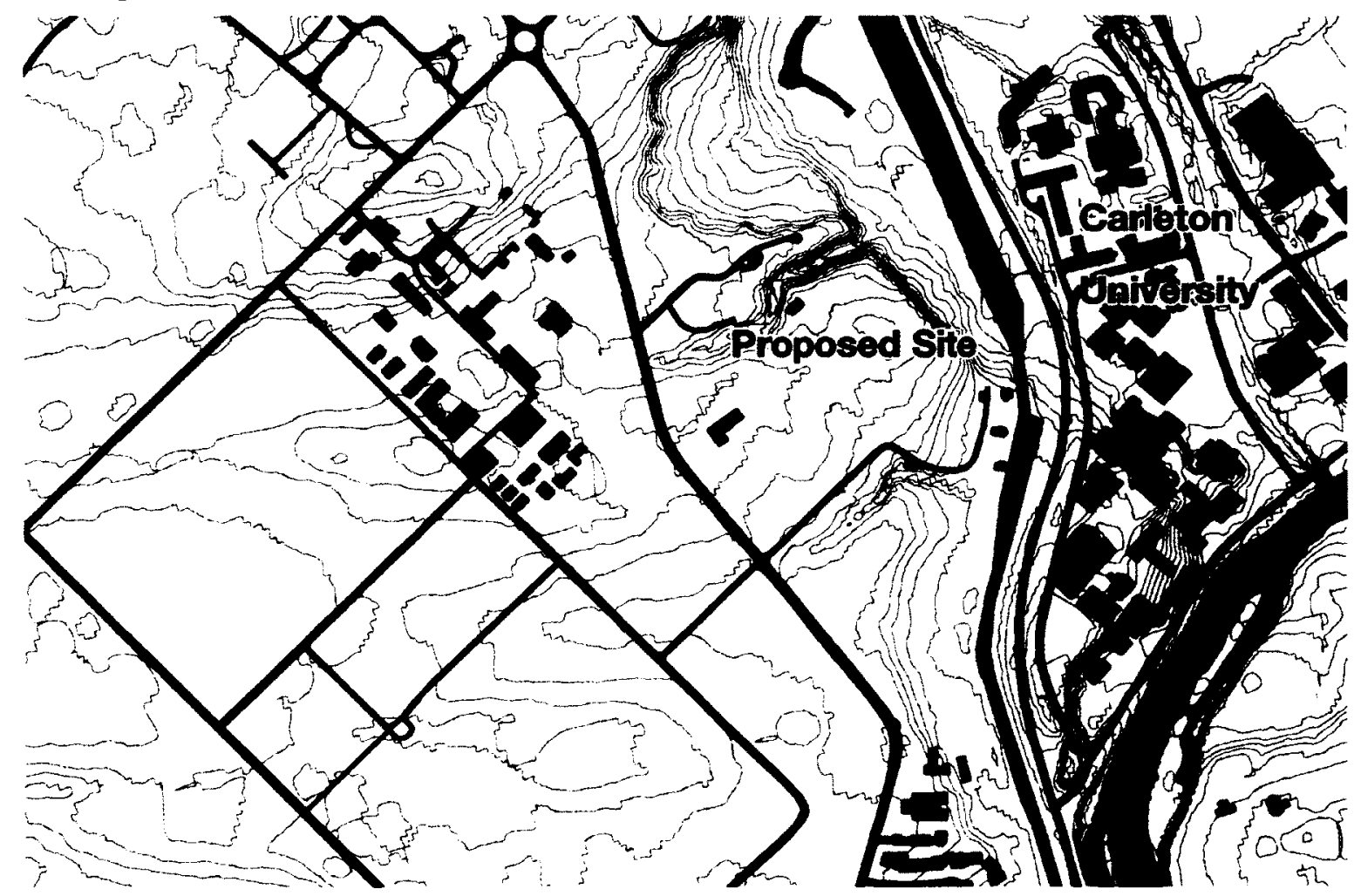

Figure31: Site 

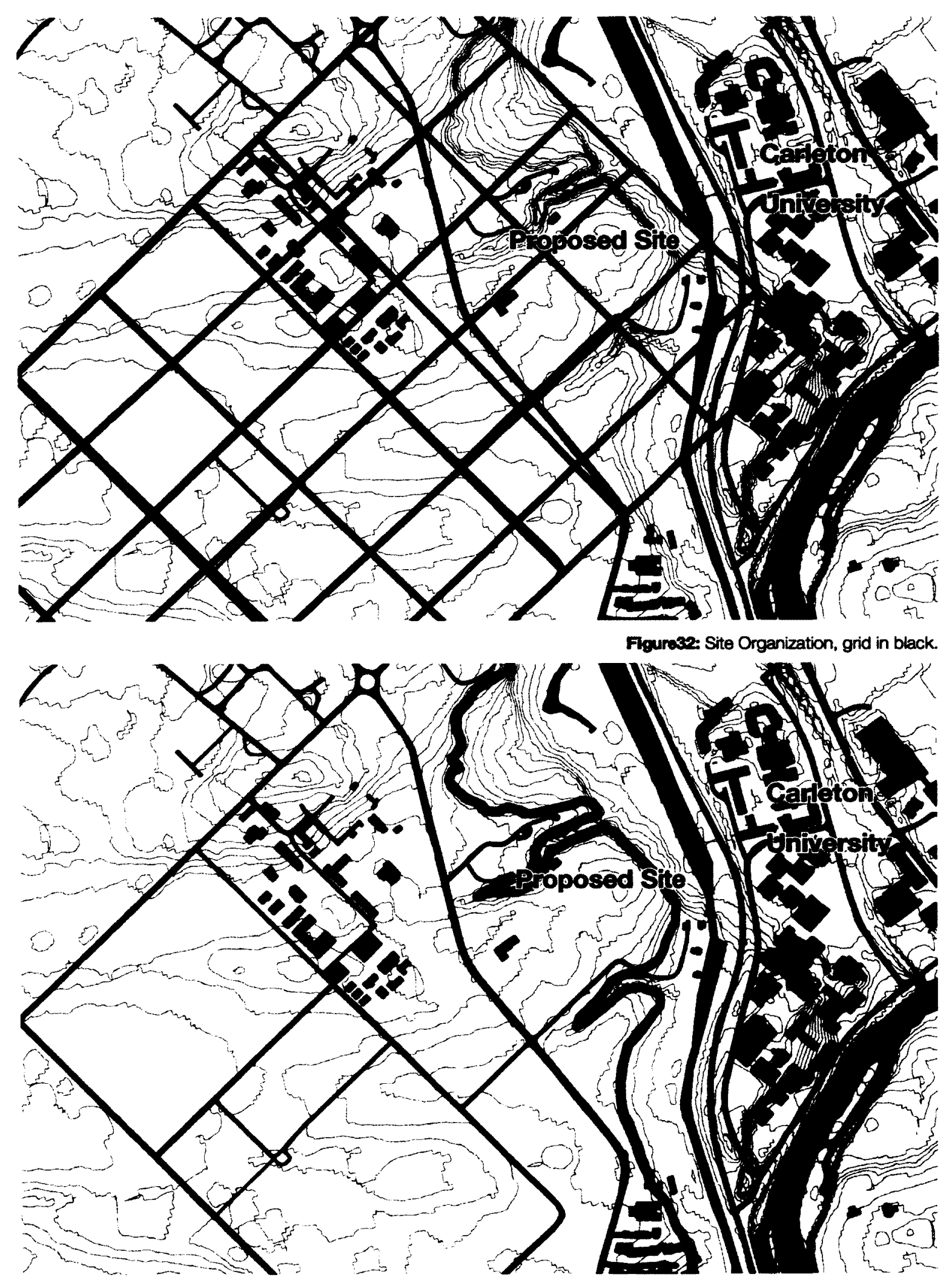

Figures3: Curvilinear site division, marked in black. 


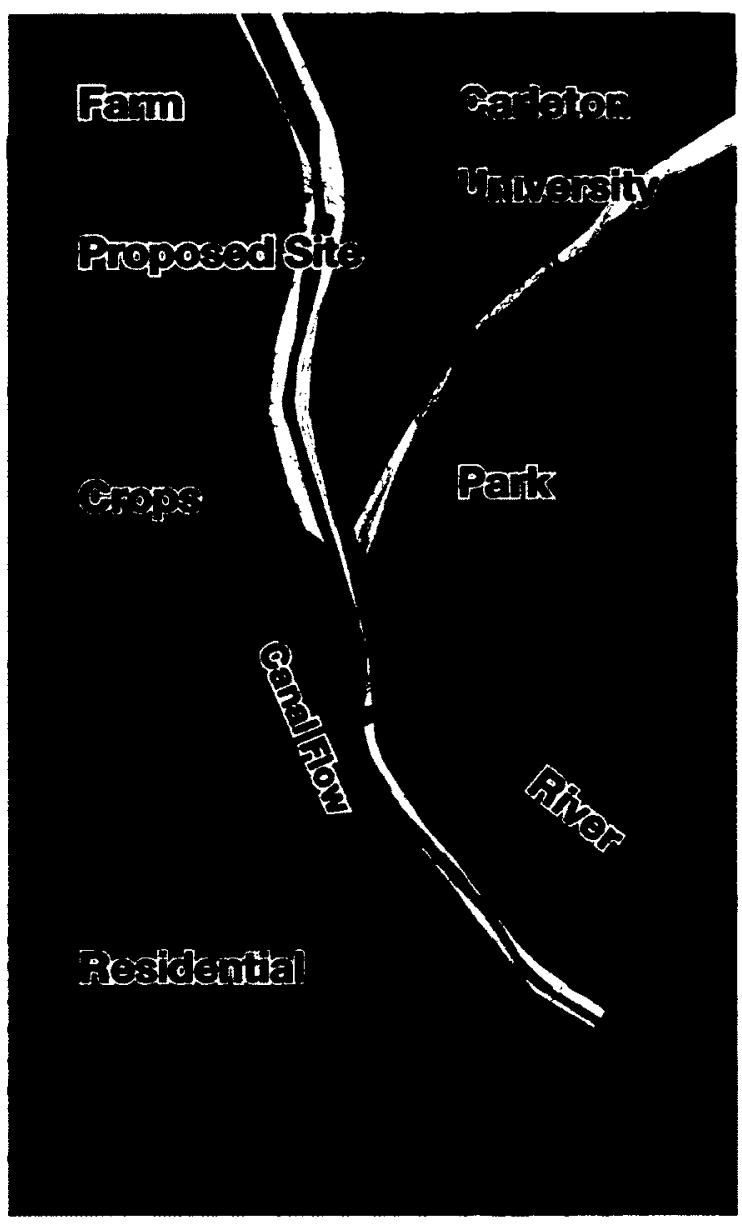

Figures4:

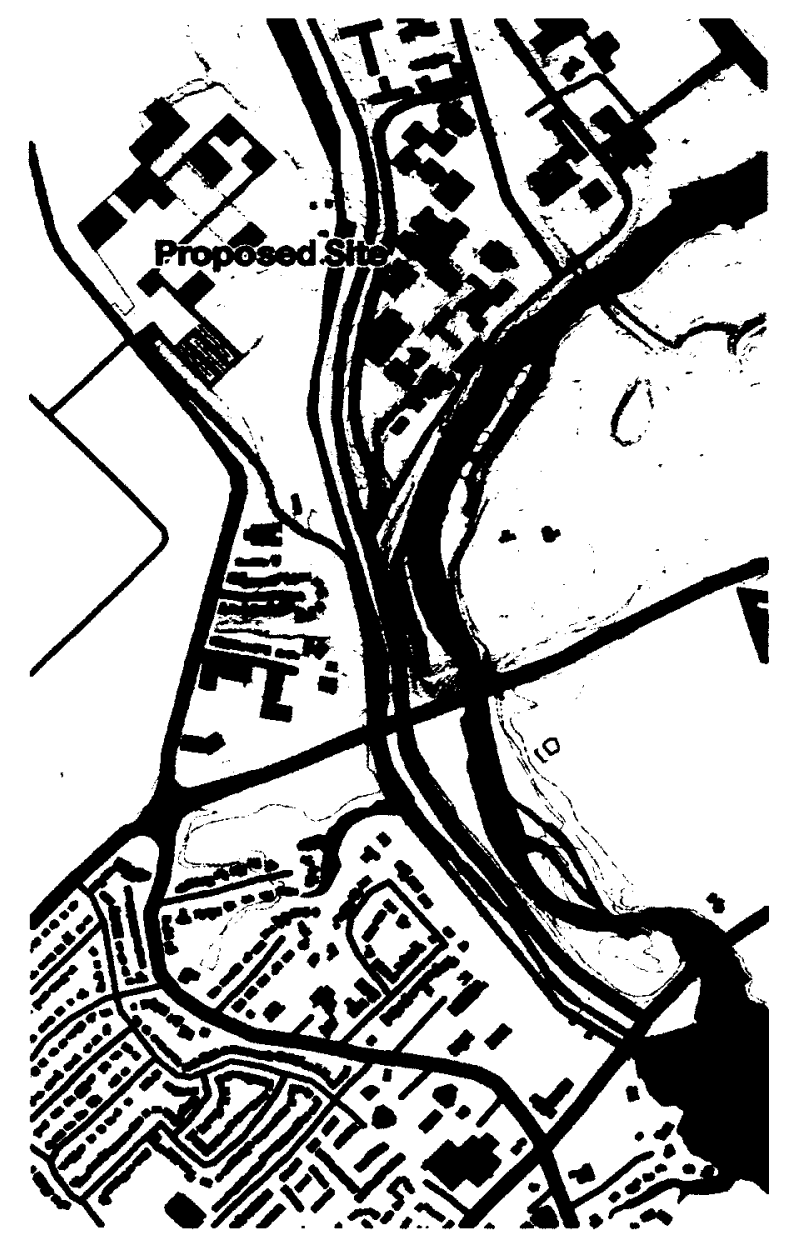

Figures5: Aqueduct to the Hogsback locks indicated in

orange.

water circulation. A related challenge involves the need to achieve a high enough entry point for the water to be able to flow using gravity alone. It was decided that water must be channeled from the next set of locks at Hogsback. After drawing out the aqueduct, starting from the site to Hogsback, it became evident that the "aqueduct" channel would be too long given the scale of the project (Figure 36). While mechanical pumping is not optimal, it will be done at the beginning of the water treatment sequence to elevate the water to the necessary height. As there is a topographical drop, the pumping will be minimal. Pumping was considered the better option than the aqueduct because the duct would disturb kilometres of forested area. Hence, the embodied energy to create the duct would have been 


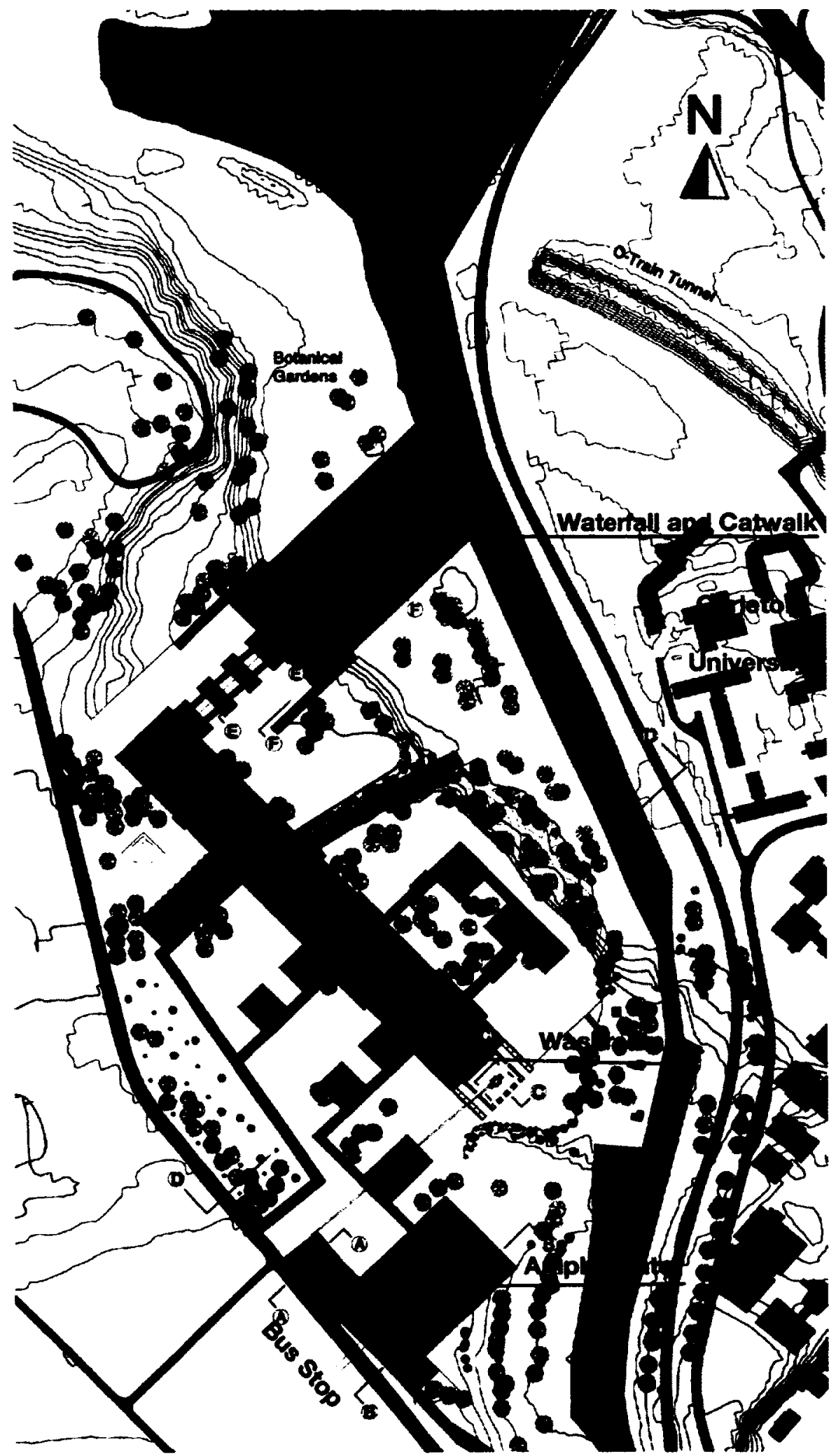

Figures6:

Park Plan 
larger than the energy to pump the water. The intention is to use solar energy to allow this pumping, with solar panels to be placed at the southern end of the site beside the entry point of untreated Canal water into the park. The design is meant to be an eco machine like that of the Omega Institute where natural processes clean the water through methods that speed up the process.

The water enters the park at the same point that people enter the park, which is to say, the bus stop. As the park is meant to teach the public about water treatment, like that of the Living Water Garden, the process must be made clear

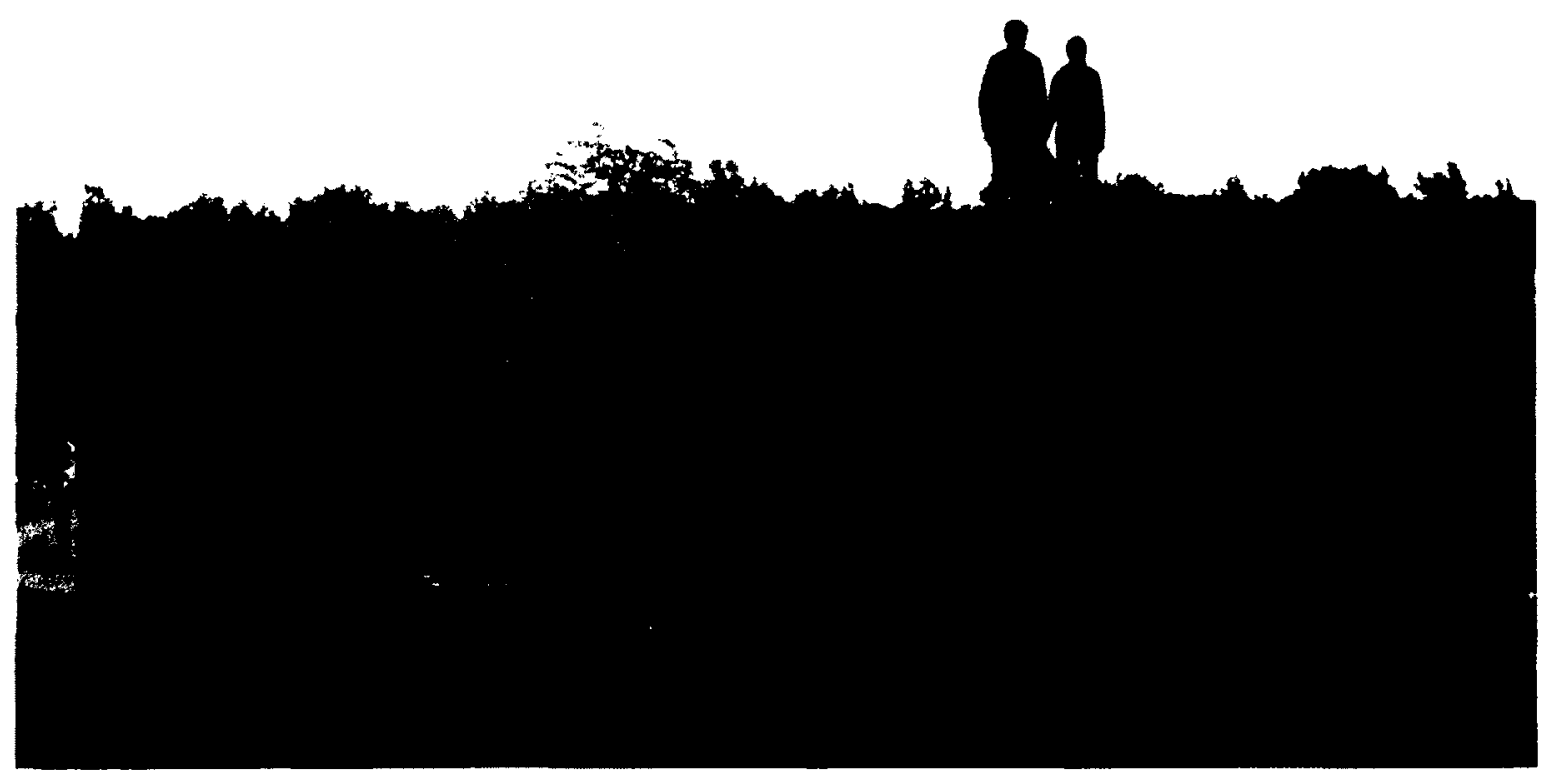

Figures7: Bus Stop

and obvious. It is also important for people to see how dirty the water is before treatment and how clean it is after treatment. This is also similar to the Living Water Garden in the few paths leading from that park to the polluted river. The water is 


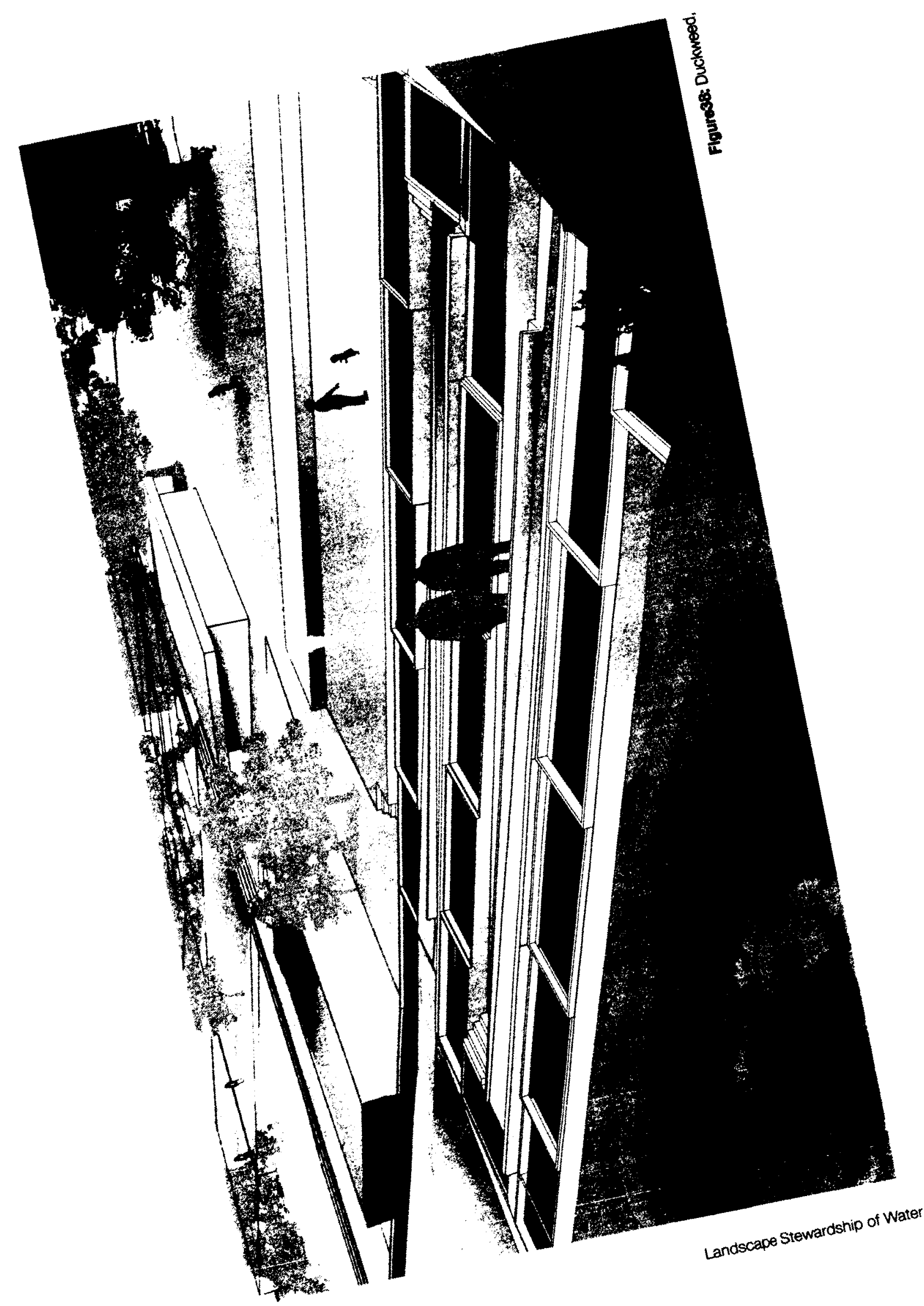




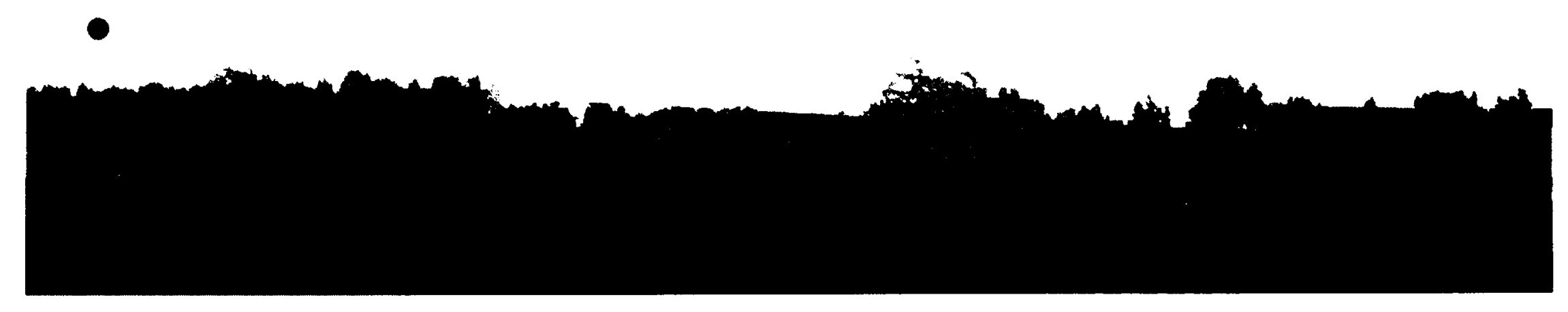

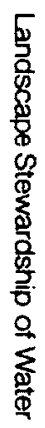

Figurese: Duckwed and Amphitheatre, image in progress. 
transported through a channel level with the ground and will have large stepping stones with small gaps with water for people to walk across. Those arriving in the bus shelter must walk across the water channel to access the proposed facility. The intention is for people to step slightly in the water so that the unclean state of the water cannot be ignored. It is a way to get people in direct contact with the unclean water, and to re-enforce the idea that it should not be ignored. The stepping stones will also act as a mechanical filter for large items thrown into the water, such as, pieces of garbage, further illustrating our careless attitude towards water.

The next step was to organize the ponds and the park. The duckweed treatment (primary treatment) is the slowest moving process, so it was integrated with the amphitheater, a place to sit quietly to watch an event. The ponds intertwine with the seating and pathway through the theatre so that people move in the same direction as the water (Figure 39 and 41). The seating is situated so that duckweed ponds are both in front of and behind the person.

The next stage of treatment involves a ten-day detention pond. To keep

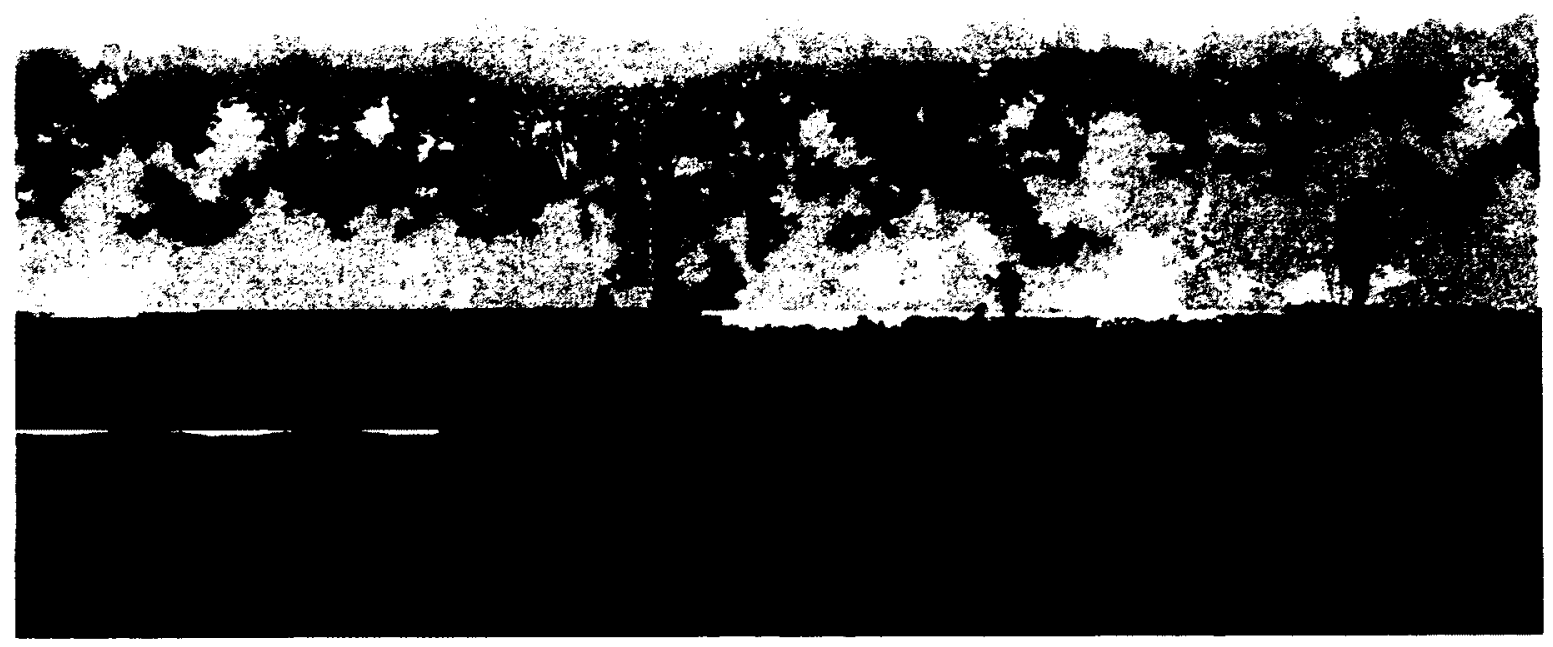

Figurewa: Detention Tanks 


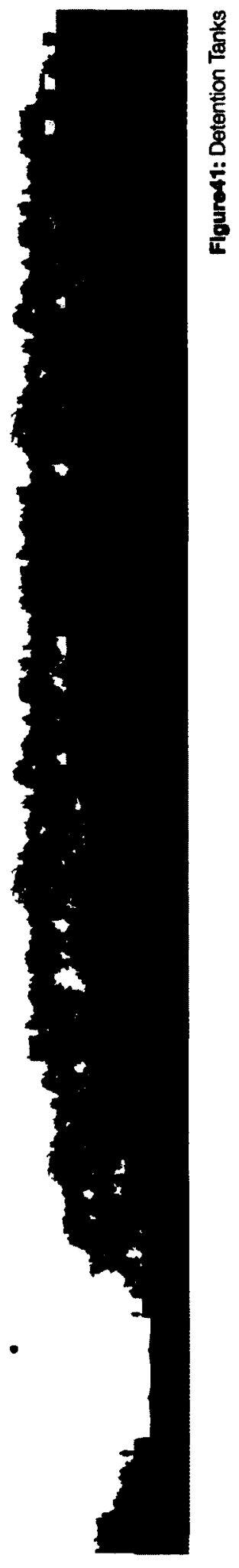




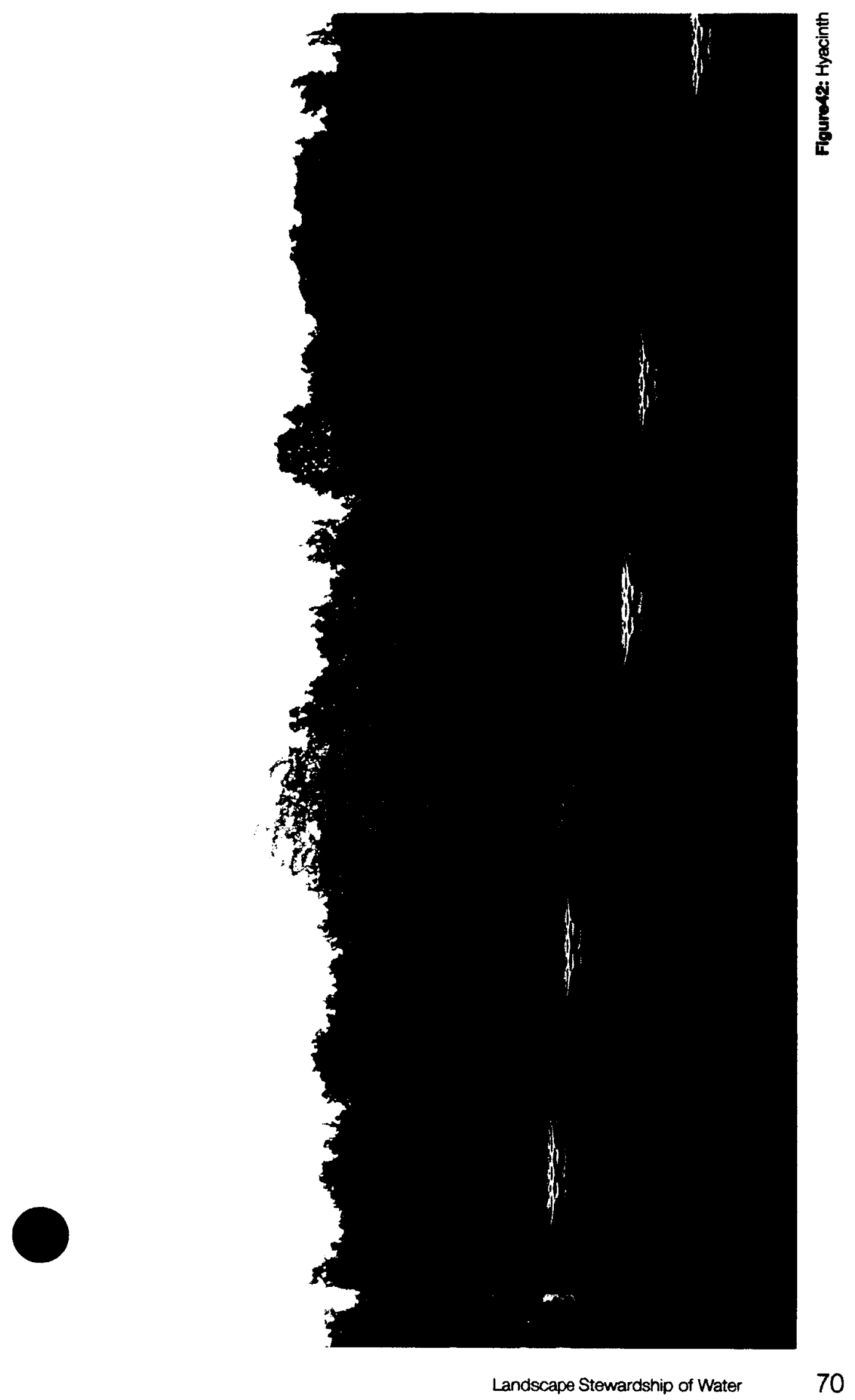




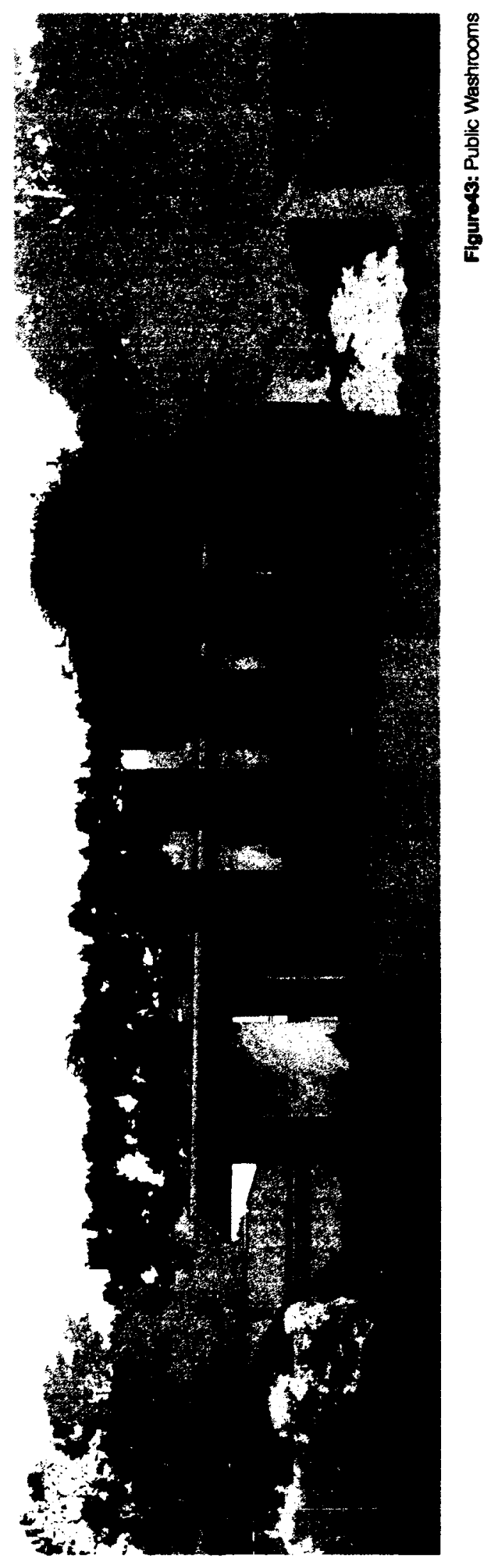




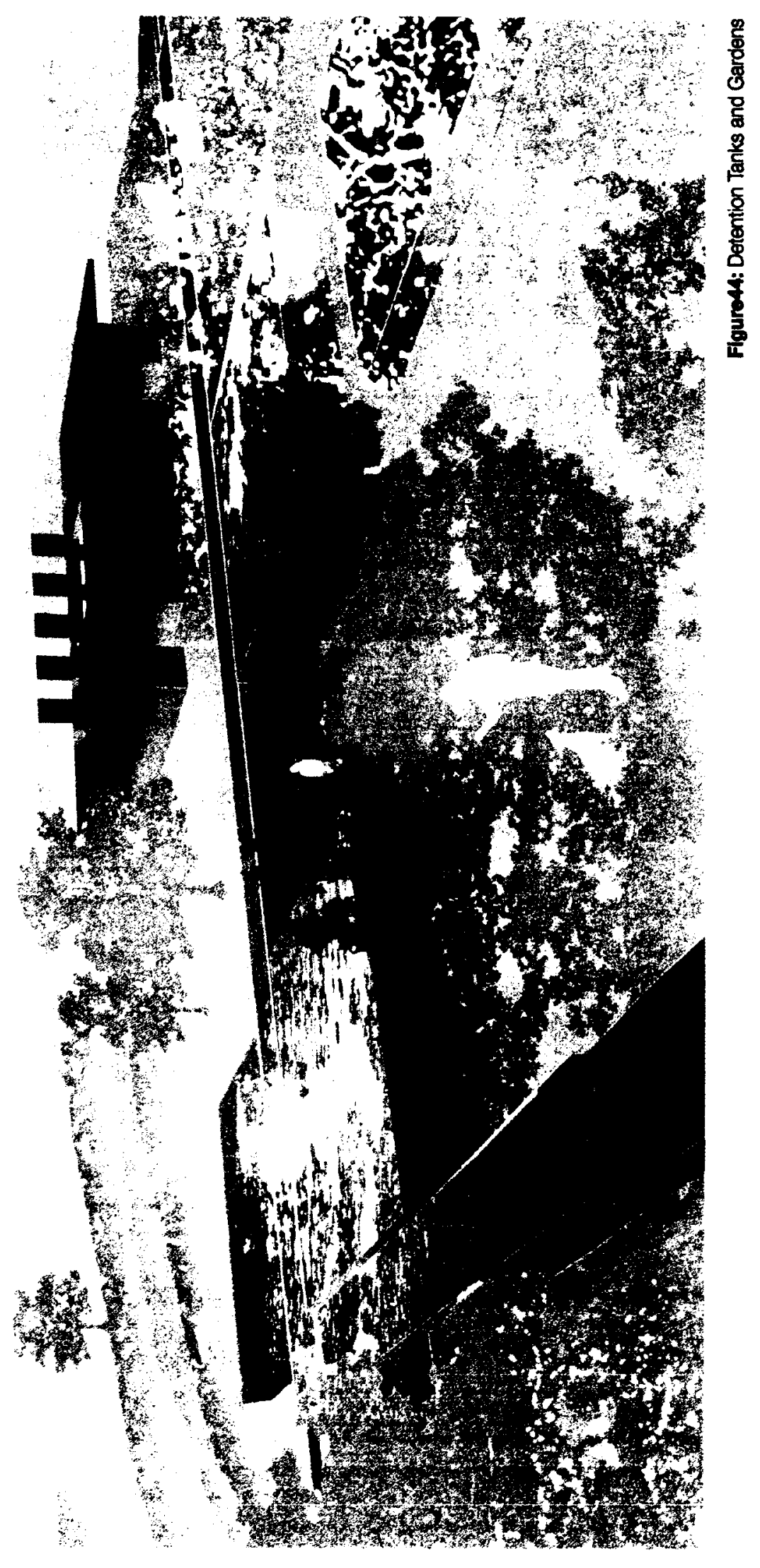

Landscape Stewardship of Water 


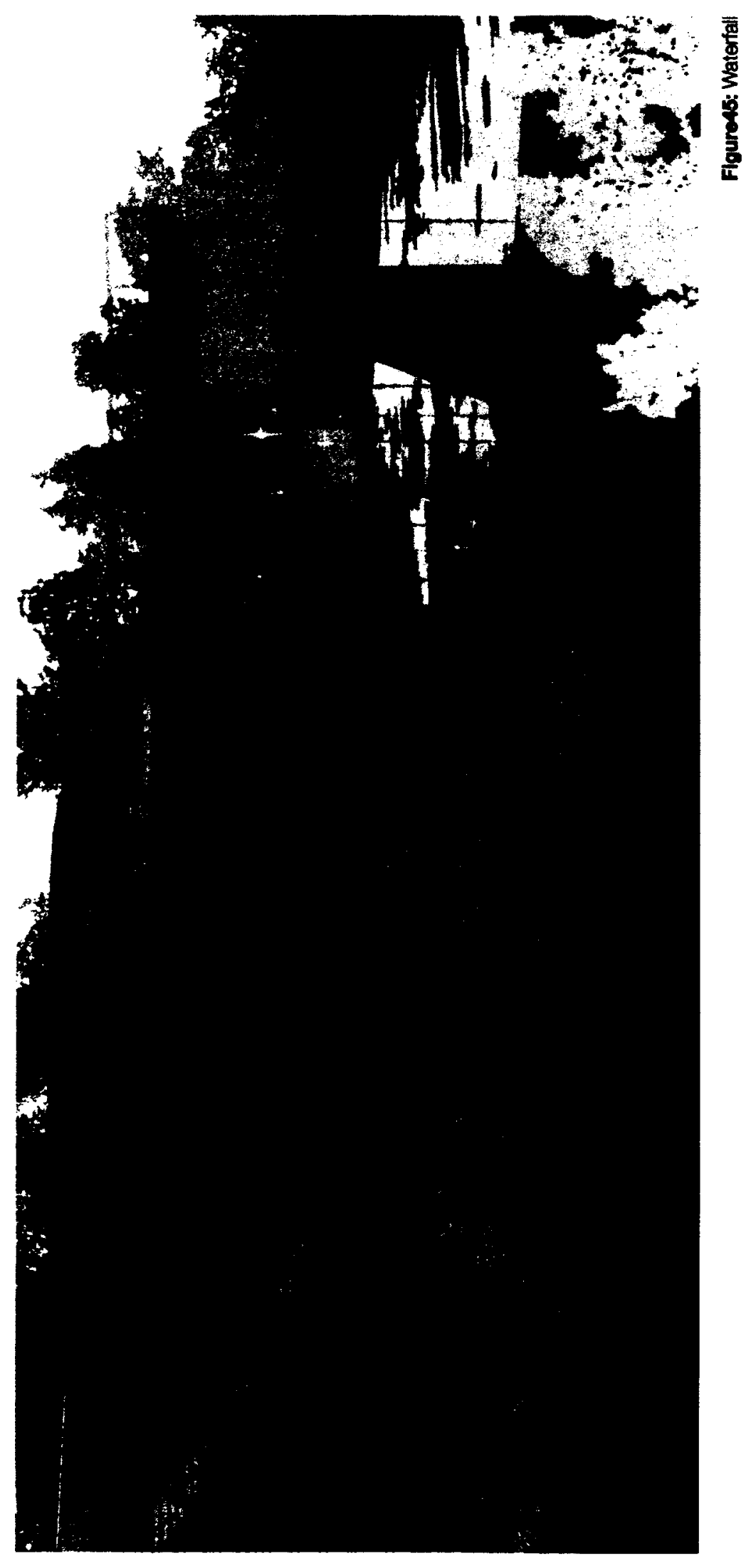


water moving through the system without interruption there will be ten ponds of this type. Every day a pond will be emptied and filled again. The detention tank lets the water settle, and hence movement is, interrupted. Gardens addressing different themes such as plant themes are geared towards particular uses for example: children, dogs, or the elderly, will find individuated spaces between tanks. This idea is from Olmsted's concept of having parks for all ages and social classes to help relieve social stresses in the city. The gardens are the human destinations as the ponds are strictly for water treatment, albeit they are visually appealing. Visitors can stay by the ponds, and then move on to the next water treatment stage, or to another garden.

The final stage of cleaning involves the secondary water treatment, which relies upon water hyacinth. This stage moves water much more quickly than the previous stages. Water will travel from pond to pond via "sinks" like those of Wilkes's water sculptures. The sculptures will add to the sensual experiences of sound and touch for the people walking through. After this treatment, the clean water will be returned to the Canal. Like Central Park, which had a huge city-wide effect providing access to outdoor public space, the newly cleaned Canal will contribute to new social and recreation places all along its banks until it merges with the Ottawa River. The Canal water will be clean enough for swimming. The Canal itself will be the swimming area, with the intermittent park space all along its banks as "beaches".

Two important architectural elements of the park are the public washrooms and the moment in which the clean water enters back into the Canal. The public washrooms must display and use water with a sense of awareness. The toilets can operate without water if the waste is mixed with ashes from wood, or other such organic material to help biodegradation. The issue of smell can be resolved if the 


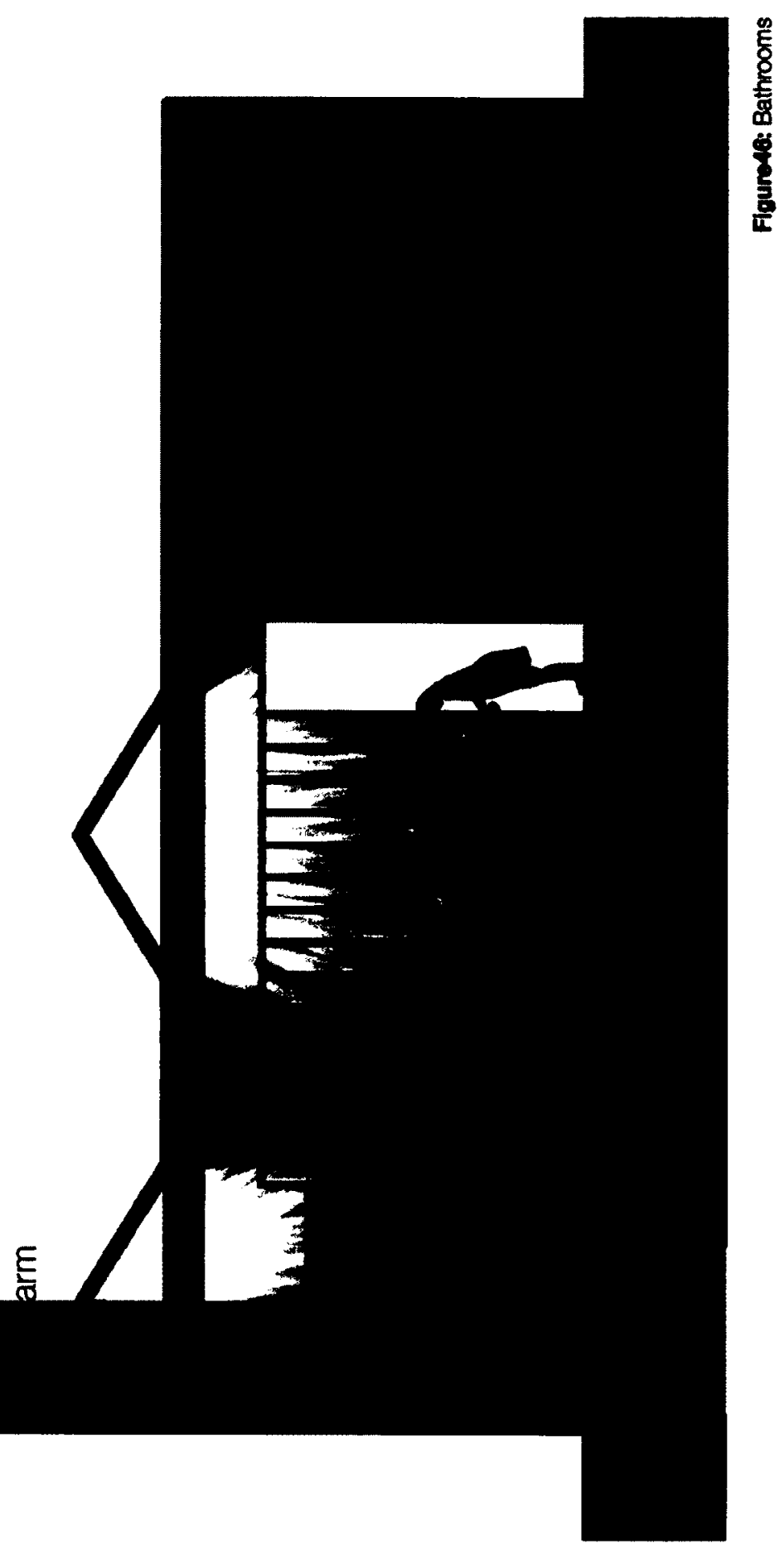




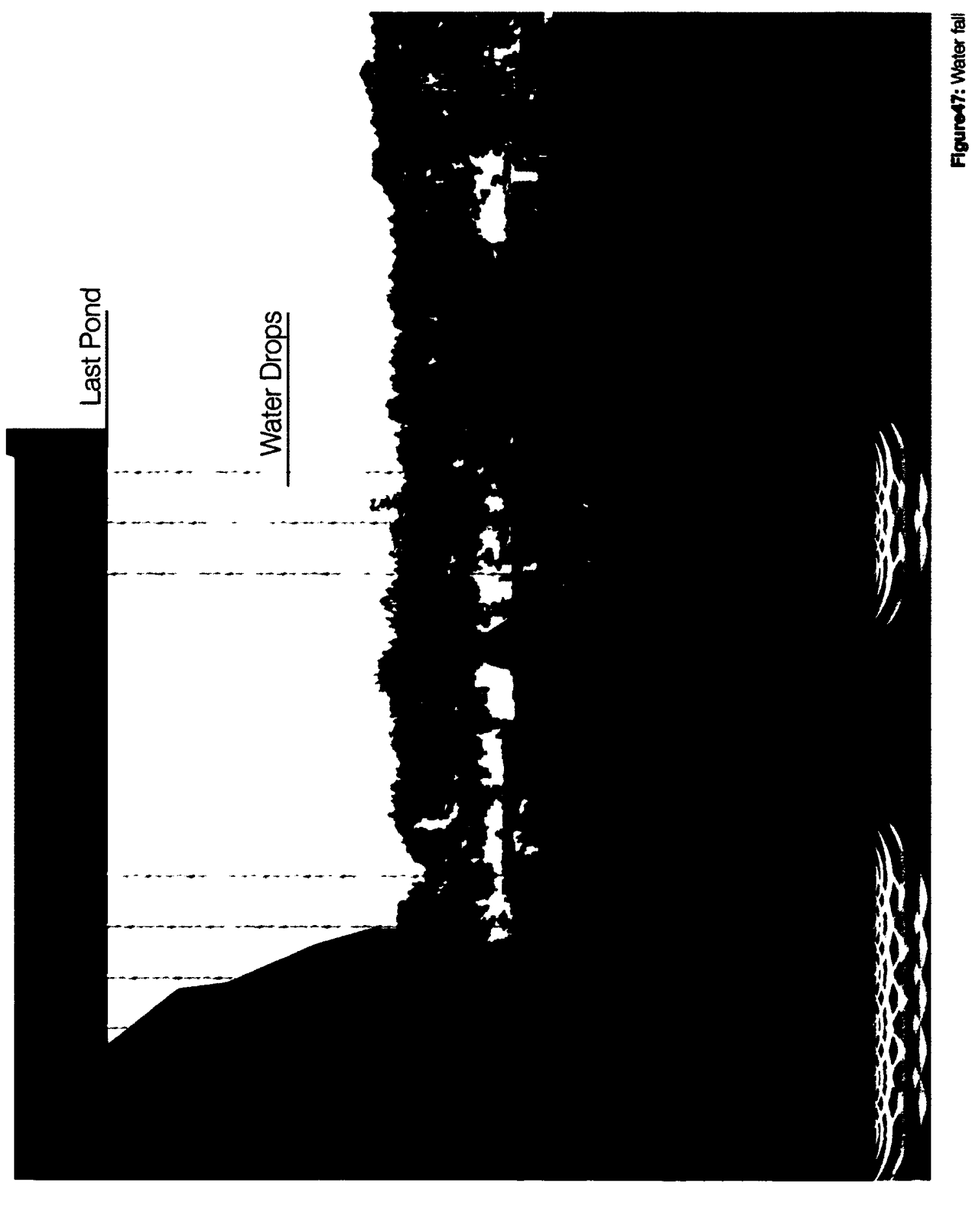


architecture encourages a controlled breeze through the building (Figure 45). Sinks will be sculptural and oscillate the water, stimulating one's sense of sound. After they water use the water, it will go back into the water purification system. Gray water will be cleaned in the treatment ponds, while sewage will be put into a septic-tank environment so that bacteria can break it down. People must be aware that after use the water must be cleaned again to balance the grey water that was just created. The system is cyclical to create balance.

The cleaned water will enter the Canal by a small waterfall. The water will be on a platform, several meters above a small pond, connecting to the water outlet. From the platform, the water will trickle down on to one of many hundreds of thin stainless steel cords (Figure 46). Each drop of water will be displayed as it travels down these cords. Each drop will be illuminated as the sun shines on it. If the wind should blow, those nearest will be gently sprayed will these drops. The waterfall will symbolize the individual purity of each drop of water before returning it to the landscape. This moment is about that perfection which we seek discussed by Downing: we seek out natural beauty because it fulfills a part of human nature that objects of utility do not. There will be a catwalk through the cords of water so that people may cross through the water and enjoy the glittering space of water. 


\section{Conclusions}

The project is aimed towards creating a better city. Ottawa's waterfronts are in need of renewal and this project is one way start addressing the problem. Cleaning the Canal water is the proposed project's biggest strength. Apart from being a tourist attraction in the winter the Canal is a part of many Ottawa festivals, such as "Winterlude" and the "Tulip Festival". The project also transforms the symbolism of the Canal itself. Once a military construction, then later used for commercial transportation, the Canal is now a historical site. It is used by boaters for recreation identifying it as desirable place to travel through. Now that its banks are protected, little can be done to manipulate its physical appearance. However, this project does because it changes the condition of the water so that is becomes more than just a scenic landscape. It becomes more than a means of circulation but a destination in itself. It makes sense to commence an initiative to clean Ottawa's water starting with such an important waterway. Given the inadequate water treatment facility of Ottawa, this facility also demonstrates a different approach to chemical methods of cleaning.

Although this project started by talking about potable water, the fact is the laws concerning water are very strict allowing for little variation. The project does not end by creating potable water for this reason. Though it is safe to use natural methods to clean potable water the law does not yet allow for it. That said, the project does introduce a new method to the public, establishing future research on water for the city.

While the effects on the environment here are in fact small, they will be large if it is looked as an example for future water care. The canal will still be impacted by boat pollution and rain run-off which effect most waterways. These issues go 
beyond design and into the mentality of the people. The goal of this proposal is to counteract the negative effects of human impact, it benefits the ecosystem in ways the current Ottawa water treatment plant does not. The project is attempting to set an example for the future of water with-in the urban landscape. Our cities are places of pollution, noise and sickness in many regards due to our own negligence; this design is an effort to take a step in a progressive direction to resolve some of these issues.

The park also aims to educate youth about water pollution. This can be done through the tours already provided by the Experimental Farm. One way in which a park can relax social tensions is by providing a place for children to play; space for recreation is important, especially for the development of youths. Such space is not always readily available to those how live in the city. Children who do not receive the proper support at home often find comfort in forming their own family with children in similar circumstances, this can lead to juvenile delinquency and thus gangs. ${ }^{75}$ Gangs lead to crime which result in racial prejudice and a general mistrust between social groups. Monitored playgrounds can help reduce gang activity by preventing them before they start; such playgroups provide support for children outside of the home.

Another way this park can relax social tensions is through accessibility, and by minimizing the barriers which segregate social classes. Although the park is anchored to a specific location along the Canal the project transforms the span of the Canal itself. This allows the park's influence to impact not just a few neighborhoods adjacent to the park, but all neighborhoods along the Canal. This in combination with public transportation limits social exclusion.

The park has two aspects: one is the water treatment plant and the second

75 Hall, Citios of Tomorrow, 466-7 
is the Canal's transform into a destination in summer equal to when it is a skating rink in the winter. The treatment transforms the Canal and because one can travel along the Canal, the park becomes a desired destination as well. The two conditions are symbiotic. 


\section{Illustrations}

Figure 1 Natural Resources Canada, www.nrcan.gc.ca; http://atlas.nrcan. gc.ca/site/english/maps/freshwater/consumption/domestic/interactivemap_print_large?scale $=5244128.1583798$ mapsize $=750 \% 20$ 6668 mapxy $=841606.5 \% 2025396.5 \&$ map_web=TEMPLATE\%20/home/ atlas/mapdata/ajax.html\&urlappend=

Figure 2 By Author

Figure 3 By Author

Figure 4 By Author

Figure 5 By Author

Figure 6 By Author

Figure 7 Heckscher, Morrison H., Creating Central Park, New Haven and London: Yale University Press, 2008, 51-54.

Figure 8 http://cgee.hamline.edu/rivers/lnquiry/RTT/rtt_bsy3.htm

Figure 9 http://www.google.ca/imgres?q=living+water+garden\&hl=en\&client =safari\&sa $=X \& r l s=e n \&$ biw $=1408 \&$ bih $=620 \&$ tbm $=$ isch\&prmd=imvns\&tb nid=9DNd1plhh8S9AM:\&imgrefurl=http://greenmuseum.org/c/ecovention/flowforms.html\&docid=at|xDpUdAWWOnM\&imgurl=http://greenmuseum.org/c/ecovention/sect6/damon_detail_flowforms.jpg\&w=240\& $h=160 \&$ ei $=$ N19iT6akK9S20QHiplGqCA\&zoom $=1$ \&iact=hc\&vpx=906\&vp $y=277 \&$ dur $=334$ \&hovh $=126 \&$ how $=173 \& \mathrm{t} x=83 \&$ ty $=54 \&$ sig $=114084737$ $850732187942 \&$ page $=2 \&$ tbnh $=126 \&$ tbn $w=173 \&$ start $=19 \&$ isp $=26 \& v e$ $\mathrm{d}=1 \mathrm{t}: 429, \mathrm{r}: 4, \mathrm{~s}: 19$

Figure $10 \mathrm{http} / / / \mathrm{www} . g o o g l e . c a / i m g r e s ? q=l i v i n g+w a t e r+g a r d e n \& h l=e n \& \mathrm{cl}$ ient $=$ safari\&sa $=X \&$ rls $=$ en\&biw $=1408 \&$ bih $=620 \&$ tbm $=i s c h \& p r m d=i m$ vns\&tbnid=3ERhgmmSixZeQM:\&imgrefurl=http://weadartists.org/ china\&docid=FkK4_qbapfisnM\&imgurl=http://weadartists.org/wordpress/wp-content/uploads/2010/11/10.jpg\& $w=532 \& h=357 \&$ ei $=N 19 i T 6$ akK9S20QHiplGqCA\&zoom $=1$ \&iact $=$ rc\&dur $=362 \& \mathrm{sig}=1140847378507$ $32187942 \&$ page $=2 \&$ tbnh $=138 \&$ tbn $w=184 \& s t a r t=19 \&$ ndsp $=26 \& v e d=1 \mathrm{t}$ : $429, r: 7, s: 19 \& t x=94 \& t y=80$

Figure 11 Wilkes, John (2009). Flowforms: the Rhythmic Power Of Water. First published in 2003 By Floris Books. Pp. 71.

Figure 12 Wilkes, John (2009). Flowforms: the Rhythmic Power Of Water. First published in 2003 By Floris Books. Pp. 102.

Figure 13 Wilkes, John (2009). Flowforms: the Rhythmic Power Of Water. First published in 2003 By Floris Books. Pp. 89. 
Figure 14 Berkebile, Bob and McDowell, Stephen and Lesniewski, Laura (2010). Flow. California: ORO editions, Publishers of Architecture, Art and Design. Pp. 21.

Figure 15 Berkebile, Bob and McDowell, Stephen and Lesniewski, Laura (2010). Flow. California: ORO editions, Publishers of Architecture, Art and Design. Pp. 46.

Figure 16 Berkebile, Bob and McDowell, Stephen and Lesniewski, Laura (2010). Fow. California: ORO editions, Publishers of Architecture, Art and Design. Pp. 17.

Figure 17 Berkebile, Bob and McDowell, Stephen and Lesniewski, Laura (2010). Flow. California: ORO editions, Publishers of Architecture, Art and Design. Pp. 30.

Figure 18 Berkebile, Bob and McDowell, Stephen and Lesniewski, Laura (2010). Flow. California: ORO editions, Publishers of Architecture, Art and Design. Pp. 39.

Figure 19 Statelet Imaging From the Carleton University data base

Figure $\mathbf{2 0}$ By Author

Figure 21 By Author

Figure 22 Statelet Imaging From the Carleton University data base Modified by Author

Figure 23 Statelet Imaging From the Carleton University data base Modified by Author

Figure 24 Statelet Imaging From the Carleton University data base Modified by Author

Figure 25 Statelet Imaging From the Carleton University data base Modified by Author

Figure 26 Statelet Imaging From the Carleton University data base Modified by Author

Figure 27 By Author

Figure 28 By Author

Figure 29 By Author

Figure $\mathbf{3 0}$ By Author

Figure 31 By Author

Figure 32 Drawings by Author 
Figure 33 Drawings by Author

Figure 34 Drawings by Author

Figure 35 By Author

Figure 36 By Author

Figure 37 By Author

Figure 38 By Author

Figure 39 By Author

Figure 40 By Author

Figure 41 By Author

Figure 42 By Author

Figure 43 By Author

Figure 44 By Author

Figure 45 By Author

Figure 46 By Author

Figure 47 By Author 


\section{Bibliography}

2010 Annual Combined Sewer Overflow Control Period Reporting, Memo to Members of Council from General Manager, Environmental Services DepartmentJune 3, 2011.

Abbasi, T. and Abbasi, S.A., Sources of Pollution in rooftop Rainwater Harvesting Systems and Their Control, Critical reviews in Environmental Science and Technology, 41:2097-2167, 2011.

Abram, David, The Spell of the Sensuous. New York: First Vintage Books, a Div ision of Random House Inc., 1996.

Allan S. Crowe, Carol J. Ptacek, David L. Rudolph and Rick McGregor. "Threats to Sources of drinking Water and Aquatic Ecosystem Health in Canada". Environment Canada; http://www.ec.gc.ca/inre-nwri/default. asp?lang=En\&n=235D11EB-1\&offset=13\&toc=show\#cur

Berkebile, Bob and McDowell, Stephen and Lesniewski, Laura. Flow. California: ORO editions, Publishers of Architecture, Art and Design, 2010.

Centralpark.com; http://www.centralpark.com/guide/history.html

City of Ottawa Landfill Sites. http://www.ottawa.ca/garbage_recycle/landfill/index_ en.html 
Church, Andrew. The attitudes of recreational user representatives to pollution reduction and the implementation of the European Water Framework Directive. Brighton UK. University of Brighton, 2010.

Didler, Suzzanna. "Water Bottle Pollution Facts". National Geographic by Demand media; http://greenliving.nationalgeographic.com/water-bottle- pollution-2947.html

Downing, Andrew Jackson, The Architecture of Country Houses, New York: Da Capo Press, 1968.

Giacomo, Panico. "Wildlife Fouling Ottawa beaches", CBC News Aug 21, 2011, http://www.cbc.ca/news/canada/ottawa/story/2011/08/21/ottawa-beachadvisories.html

Granger, Frank. Vitruvius On Architecture. Cambridge, Massachusetts, Harvard University Press, Vol. 1, 1929.

Greenmuseum.org. http://greenmuseum.org/content/artist_index/artist_id-62_ nosplit-z.html

Hall, Peter. Cities of Tomorrow Third Edition. Malden, MA, USA: Blackwell Publishing, 2002.

Heckscher, Morrison H., Creating Central Park, New Haven and London: Yale University Press, 2008. 
Hiew, Mark, Live Water Garden, 2008, http://www.morechengdu.com/venue/forcomplete-tourism-listings-click-here/tourism/venue-2242-open.html

Illich, Ivan. $\mathrm{H}_{2} \mathrm{O}$ and the Waters of Forgetfulness. London: Marion Boyars Publishers, 1986.

Interpools: http://www.interpools.com/

Keepersofthewaters.org, http://www.keepersofthewaters.org/lwg.cfm

Natural Resources Canada. www.nrcan.gc.ca; http://atlas.nrcan.gc.ca/site/ english/maps/freshwater/consumption/domestic/interactivemap_print_larg e?scale $=5244128.158379 \&$ mapsize $=750 \% 20666 \&$ map $x y=841606.5 \% 20$ 25396.5\&map_web=TEMPLATE\%20/home/atlas/mapdata/ajax. html\&urlappend=

Rees, William. "Understanding Urban Ecosystems: An Ecological Economics perspective", In Understanding Urban Ecosystems. Edited by Alan Berkowits. New York: Springer-Verlag, 2003.

Rosenzweig, Roy and Blackmar, Elizabeth. The Park and the People: A History of Central Park. Ithaca New York: Cornell University Press, 1992.

Schuyler, David. Apostle of Taste: Andrew Jackson downing 1815-1852. London: The Johns Hopkins University Press, 1996. 
Sewell, John. The Shape of the City Toronto Struggles with Modern Planning. Toronto, Buffalo and London: University Of Toronto Press Incorporated, 1993.

Smith, Helen. Ottawa's Farm: A History of the Central Experimental farm. Renfrew, Ontario: General Store Publishing House, 1996.

Walls-Thumma, Dawn, How can water Pollution Affect Animals, Homes and Health?, Demand Media, National Geographic; http://greenliving.nationalgeographic.com/can-water-pollution-affect-animals-homes-health-2921.html

Water Environment Federation. Natural systems for Wastewater Treatment Third Ed.: Manual of practice No, FD-16. Alexandria: Water Environment Federation, 2010.

Wilkes, John. Flowforms: the Rhythmic Power Of Water. First published in 2003 By Floris Books, 2009.

Williams, Raymond. Keywords. New York: Oxford University Press, 1976.

"Yes" magazine, Feb 16,2012, http://www.yesmagazine.org/planet/living-watergarden-on-the-fu-and-nan-rivers 